\title{
The Evaluation of National Education Councils from the point of view of Teachers' Problems (1980-2000)*
}

\author{
Rafet AYDIN**
}

\begin{abstract}
The main purpose of this research is the evaluation of the problems of the teachers that were discussed at the National Education Councils, between the years 1980 - 2000. From this perspective main problems of teachers that were taken up at the National Education Councils examined using "scanning model". In this research, it has been accepted that alongside with their duty and responsibilities, teachers have problems while they perform their educational and teaching activities. The problems of teachers are gathered under six sub-headings which are the number of teachers, the problems of educating the teachers, the legal state of teachers, the economical problems of teachers, the problems being organized as teachers and the problems of publications. Again in this research, how much was these problems of teachers reflected at the National Education Councils, and, whether how much the requested solutions for these problems effected the policies and the implementations of the Ministry of National Education, are evaluated.
\end{abstract}

Key Words: Teacher, the job of teaching, the problems of teachers, National Education Councils.

\footnotetext{
* This research is a part of doctorate dissertation "Evaluation on the Policy and Implementations of the Ministry of National Education and on the Problems of Teachers Discussed on Education Councils and Academic Educational Congresses held in Turkey (1920-2004)".

** Dr., Mehmet Akif Ersoy University, Faculty of Education. raydin@mehmetakif.edu.tr
} 


\section{SUMMARY}

Purpose and Significance: Every community in the world is interested in education and teachers, and they have seen them as developing and progressing elements. So they have given them important tasks and responsibilities. This is the same in Turkey. It has been accepted that the reality which will develop the nation and the country, and make progress in the life standards of nation, is education and teachers. The teaching as a profession as being holly and important. But alongside with their tasks and responsibilities teachers have problems. The problems of teachers have still been the matter of some scientific meetings and researchers. National Education Councils are one of the (maybe the most) most important scientific meetings.

National Education Councils are scientific meetings, to which the agents of the Ministry of National Education, scientists, pedagojists and the other representatives from the institutes, related to education, have joined and in which the many problems of Turkish National Education are discussed and the suggestions for the solution are prepared. So from this perspective Councils are scientific meetings that have a scientific quality and wide basis of knowledge. Since the first years of the Republic, these meetings have been hold in many different dates and under different names. The Councils have important role in the solution of problems of education and the formation of Education system and its adaptation to the conditions of the age.

The main purpose of this study is the evaluation of the problems of teachers and the solutions for these problems that were taken up at the National Education Councils, between the years 1980 - 2000. From this perspective "What were the main problems of teachers that were taken up at the National Education Councils? And also how much did the problems of teachers that were taken up in these Councils effect the policies and the implementations of the Ministry of National Education?

Methodology: In this study "scanning model" is used. Scanning models are the approaches, aiming to describe the case as it is, which was occurred in the past or is still existing (Karasar, 2005; 77). So in this research, it is aimed to describe the problems of teachers that were taken up at the National Education Councils between the years $1980-2000$ as they are. From this perspective the research is on a descriptive level. When descriptive researches are done addressing to the past, they expose the matter "what was is?". In the scientific studies, descriptive research is the firs and basic study action. This technique has a crucial importance for the comprehension and the investigation of the knowledge. Most of the problems of education are within the descriptive quality (Balc1, 2001; 21). 
The period that the research analyzes is also important for the problems of teachers and research sources. Because in this period there are differences in the problems of teachers, as it exists fort he education of teachers. For example, while the instution that educates and employees the teachers, was the Ministry of National Education before 1982, the intuition which is responsible for the education and the employment of the teachers, differs. This task was given to the Universities by the 2547 numbered law of Higher Education

In this research National Education Councils are analyzed within the frame of the number of teachers, the legal state of teachers, the economical problems of teachers, the problems of being organized as teachers and the problems of publications. Besides the reflection of the problems, being taken up at the Councils, to the policies and the implementations of Ministry, are evaluated.

Results and Suggestions: Some of the results and the suggestions of the research are; the problems of teachers are one of the old problems of Turkish Education System. The problems of the teachers are the matter of the debate at the scientific meetings and discussions, in which the problems of Turkish Education System are discussed. There are lot problems, arising from the education and employment of the teachers to their rights of liberty. And this has become the subject of many scientific researches. The problems of teachers have been accepted and discussed as one of the basic problems at the National Education Councils, in which the problems related to education are discussed. But he problems of teachers and the solutions for these problems which were discussed at these Councils and scientific meetings, have not been considered and studied in the scientific studies as it was expected.

One of the first meetings of national Education Councils was held in 1939. After that date, the matter of problems of teachers and education has usually been discussed and, new suggestions and solutions have been requested according to necessities of the period, and some new decisions have been accepted to be practiced. These meetings, decisions, discussions and suggestions for the problems of teachers have caused changes in the implementations and the policies of the Ministry. Some times these changes have stayed on the paper.

In the National Education Councils, it can be seen that the problem of education of teachers have generally been discussed much more than the other problems of teachers, which have been discussed slightly. The legal state of teachers is another matter that has been discussed. While this problem has been in some council, it could not be discussed in some others. 
At the Councils, the problems of teaching as a profession and the suggestions for solutions have always been discussed and new suggestions for solutions and new models have been suggested. At these meetings the existence of problem has always been accepted, but an original and rooted solution could not be found. Only the teaching as a profession and the matter that the teachers have responsibilities and tasks, and the greatness of this profession have always been stressed and said again. But the expected results have not been seen.

As it can be understood from these results, it is impossible to find permanent solutions for the problems and to do a right and permanent work without the support of scientific decisions. For this reason Ministry of National Education should be an authority to implement the ideas and decisions of scientists and philosophers of the country. So even if the minister's change, the decisions that have been accepted based upon the scientific basis, should never be changed till the new scientific decisions are accepted.

Finally, it can be said that the evaluations and the solutions, related to problems of teachers and the education, should be done by scientists in scientific methods. The problems of teachers should be evaluated without politics. The Ministry of National Education should be the followers and appliers of the decisions. The Ministry should behave according to scientific data and findings, not with the political anxieties. National Education Council has a great role in the solution of the problems of teachers as it performs in the other problems education. 


\section{Türkiye'de Öğretmen Sorunları açısından Milli Ĕgitim Şuralarının Değerlendirilmesi (1980-2000)*}

\section{Rafet AYDIN**}

ÖZ: Bu araştırmanın temel amacı, 1980-2000 yılları arasında Millî Eğitim Şûralarında ele alınan öğretmen sorunları ile bu sorunlara getirilen çözüm önerilerinin değerlendirilmesidir. Bu genel amaç çerçevesinde; Millî Eğitim Şûralarında ele alınan başlıca öğretmen sorunları neler olmuş ve hangi sorunlar ne ölçüde şuralarda yer almıştır? Ayrıca bu Şûralarda ele alınan öğretmen sorunları Millî Eğitim Bakanlığının politika ve uygulamalarını ne ölçüde etkilemiştir? gibi sorular 'tarama yöntemi' kullanılarak cevaplandırılmaya çalışılmıştır. $\mathrm{Bu}$ araştırmada, eğitim ve öğretim faaliyetlerini gerçekleştiren öğretmenlerin görev ve sorumluluklarının yanında sorunlarının var olduğu kabul edilmiş ve öğretmen sorunları; öğretmenlerin sayısal durumu, öğretmenlerin yetiştirilmesi sorunu, öğretmenlerin hukuki statüleri, öğretmenlerin ekonomik sorunları, öğretmenlerin örgütlenme sorunları ve öğretmenlerin mesleki yayın sorunları olmak üzere altı alt başlıkta ele alınmıştır. Yine bu çalışmada, bu öğretmen sorunlarının, Millî Eğitim Şûralarına ne kadar yansıdığı, şurada ele alınan öğretmen sorunlarının ve bu sorunlara getirilen çözüm önerilerinin ve alınan kararların Millî Eğitim Bakanlığının politika ve uygulamalarını ne ölçüde etkilediği değerlendirilmiştir.

Anahtar Sözcükler: Öğretmen, Öğretmenlik Mesleği, Öğretmen Sorunları, Öğretmen Yetiştirme, Öğretmenlerin Hukuki Statüleri, Milli Eğitim Şuraları

\footnotetext{
* Bu araştırma “Türkiye'de Eğitimle İlgili Yapılan Bilimsel Toplantılarda ve Millî Eğitim Şûralarında Ele Alınan Öğretmen Sorunları ile Millî Eğitim Bakanlığı'nın Politika ve Uygulamalarının Değerlendirilmesi (1980-2004)" isimli Doktora tezinin ilgili bölümlerinin özetlenmesi ve geliştirilmesinden oluşmaktadır.

** Dr., Mehmet Akif Ersoy Üniversitesi, Eğitim Fakültesi. raydin@mehmetakif.edu.tr
} 


\section{GİRIŞ}

Eğitim, kişinin zihnî, bedenî, duygusal, toplumsal yeteneklerinin, davranışlarının en uygun şekilde ya da istenilen bir doğrultuda geliştirilmesi, ona bir takım amaçlara dönük yeni yetenekler, davranışlar, bilgiler kazandırılması yolundaki çalışmaların tümüdür. Bu yönüyle eğitim, insanın doğumuyla başlayan ve hayat boyu devam eden bir süreçtir (Akyüz; 2007; 2). Ancak eğitim denilince daha çok kastedilen planlı, programlı ve amaçlı eğitimdir.

İnsanlık tarihi ile başlayan öğretim faaliyeti, başlangıçta aile üyeleri, kabile büyükleri tarafindan gerçekleştirilmiştir. Daha sonra bilgiler artıp karmaşıklaştıkça, bu işin özel bir kurumda (okulda) ve görevi yalnızca öğretmek olan kişilerce (öğretmenlerce) yapılması benimsenmeye başlanmıştır. Öğretme-öğrenme işinin insanlık tarihi ile başladığı kabul edilirse öğretmenlik mesleğinin de dünyanın en eski mesleklerinden biri olduğu söylenebilir (Oktay,1991;187).

Günümüzde eğitimi bir sosyal sistem olarak gören bilim adamları, bu sistemin üç temel öğesinin öğrenci, öğretmen ve eğitim programları olduğunu kabul etmektedirler (Karagözoğlu,1986;34). Örgütlenmiş bütün toplumsal faaliyetler içinde eğitim, insanın mutlak olarak en önemli olduğu alandır. Eğitimde en önemli insan unsuru ise öğretmendir. Eğitimin özelliğinden dolayı bu unsurun yerini başka bir şeyle değiştirmek olanağ yoktur (Kaya, 1984; 386). Toplumun, ülkenin geleceği için öğretmen ve öğretmenlik mesleği üzerinde gereğince ve yeterince durulmalıdır. Bir eğitim sisteminin en önemli öğesi öğretmendir. İyi eğitimi iyi öğretmenler, nitelikli öğretimi de nitelikli öğretmenler yapar. Ayrıca öğretmenin eğitimöğretim etkinlikleri ve rolleri de giderek artmaktadır. Öğretmenlik milletlerin kaderini tayin eden bir meslektir (Kavcar, 1999: 11). Öğretmenler önemli bir insan sermayesini temsil ederler ve onların eğitim sürecine katkıları kalkınma yönünden en önemli etkendir. Öğretmenlerin sayısı ve niteliğine bağlı olarak eğitimin topluma katkısı da yeterli ya da yetersiz olur (Kaya,1984:184). Bu da o toplumun dünya milletler sahnesinde bulunduğu konumdan açıkça anlaşılabilir.

Toplumları geleceğe hazırlamakla görevli öğretmenlerden her toplumda ileriye dönük çok büyük beklentiler bulunmaktadır. Türk Eğitim tarihinde de toplumun öğretmenlerden beklentilerine ilişkin pek çok örnek vardır. Devlet adamları ve çeşitli eğitimciler, öğretmenlik mesleği, öğretmenlerin görev ve sorumlulukları hakkında birçok değerlendirmeler yapmışlardır.

Cumhuriyet öncesi dönemde ülkenin içinde bulunduğu olumsuz durumdan kurtarılması için bazı çareler aranmış, başta Balkanlarda yaşanan 
hezimetten ülkenin eğitim sistemi sorumlu tutulmuş ve kurtuluş çaresinin de yine eğitimde ve öğretmenlerde olduğu düşünülmüştür (Gurbetoğlu, 2007:271). Bunun için öğretmenlik mesleği konusunda bazı önemli görüşler ortaya atılmıştır. Bunlardan bazıları;

"Türkiye'yi kurtaracak ve yükseltecek ögretmenlerdir, eğitimdir."

"Öğretmenlik öncelikle ĕgitimcilik demektir. Ĕgitimcilik ise bir hünerdir; bir sanattır. Bu sanatın özel kuralları ve metotları vardır. Öğretmenin bunları bilmesi; bunun sağlanması içinde yetiştirilmesi sırasında kendilerine kazandırılması gerekir."

“Öğretmen okullarının tek amacı ögretmen yetiştirmek olmalı ve buna hizmet etmelidir."

"Öğretmenlik mesleğinin itibarının yükseltilmesi, iyi öğretmen sağlamak için gereklidir" (Akyüz, 1987; 33 ve Duman, 1991; 19) olarak sayllabilir.

Türkiye Cumhuriyeti Devleti'nin kurucusu Mustafa Kemal Atatürk, öğretmenler ve öğretmenlik mesleğinin önemi, görev ve sorumlulukları hakkında görüş ve düşüncelerini başta TBMM olmak üzere çeşitli yer ve zamanlarda, birçok zamanda öğretmenlere bizzat seslenerek dile getirmiştir. Mustafa Kemal Atatürk'ün öğretmenlere ilişkin düşünce ve sözlerinin bazıları şöyle sıralanabilir:

"Milletleri kurtaran yalnı ve ancak ögretmenlerdir. Öğretmenden, eğitimciden yoksun bir toplum, henüz millet adını alma kabiliyetini kazanamamıştır. Ona basit bir toplum denir, millet denemez. Bir toplum, millet olabilmek için mutlaka eğitimcilere, öğretmenlere muhtaçtır.” (Tekışık,1995:3-4).

"Öğretmenler, ordularımızın kazandığ zafer sizin ve sizin ordularınızın zaferi için, yalnız ortam hazırladı. Gerçek zaferi siz kazanacak, siz yaşatacaksınız ve mutlaka başarıya ulaşacaksınız." (Duman; 1991;23).

"Öğretmenler; hiçbir zaman hatırınızdan çıkmasın ki, Cumhuriyet sizden fikri hür, vicdanı hür, irfanı hür nesiller ister.”

"Öğretmenler; cumhuriyetin fedakâr öğretmen ve eğitimcileri, yeni nesli sizler yetiştireceksiniz. Ve yeni nesil sizin eseriniz olacaktır. Eserin klymeti sizin maharetiniz ve fedakârllğını derecesiyle orantıll olacaktır. Cumhuriyet; fikren, ilmen, fennen, bedenen kuvvetli ve yüksek karakterli koruyucular ister. Yeni nesli, bu özellik ve kabiliyette yetiştirmek sizin elinizdedir" (Teklşık, 1982: 11, Duman,1991: 23 ve Eke, 1983: 12)

Atatürk, bu düşüncelerini hayata geçirmek için eğitim sistemi ve öğretmenlik mesleği üzerinde önemle durmuştur. Duman'a (1987:114)göre Atatürk döneminde, özellikle Cumhuriyetin ilk yıllarında öğretmenlere, vatan, millet, cumhuriyet aşk1, özveri çok daha iyi verilmiştir. Çünkü yeni Türk devletinin kurulması, eğitimin geliştirilmesi için uygun bir ortam hazırlamıştır. 
Öğretmenlik her zaman, önemli bir meslek olarak görülmüştür. Mesleğin öneminden dolay1; öğretmenlere her zaman önemli görev ve sorumluluklar yüklenmiştir. Öğretmenlerden bu zor görev ve sorumlulukları en iyi şekilde yerine getirmeleri beklenmiş ve de beklenmektedir. Öğretmenlik, özel bir uzmanlık eğitimi gerektiren sanatsal yönü de bulunan bir meslektir. Bu kabulün neticesidir ki, öğretmenlik mesleğinin sorunları ve bunların çözümüne ilişkin çeşitli bilimsel toplantı ve çalışmalar yapılmakta, bu amaca dönük değişik etkinlikler her geçen gün artarak devam etmektedir.

$\mathrm{Bu}$ çalışmada öğretmen sorunları; öğretmenlerin yetiştirilmesi sorunu, sayısal durumları, öğretmenlerin hukuki statü sorunları, ekonomik sorunları, örgütlenme sorunları ve mesleki yayın sorunları olmak üzere altı başlık altında incelenmiştir.

\section{1. Öğretmenlerin Yetiştirilmesi Sorunu}

Cumhuriyet öncesi eğitim sistemine bakıldığında; Selçuklulardan alınan ve ilk örgün eğitim kurumları olan mektep ve medreseler, Osmanlılar zamanında geliştirilerek yaygınlaştırılmıştır. Bu kurumlar zaman içerisinde kendilerini yenileyemedikleri için bunlar dışında askeri ve sivil alanda yeni okullar açılmıştır. Geleneksel Osmanlı eğitim kurumları dışında açılan bu yeni okullar, ögretmen yetiştirme sorununu da beraberinde getirmiştir (Duman, 2005; 61).

Türkiye'de bugünkü anlamda, yani bazı meslek dersleri okutularak öğretmen yetiştirmenin tarihi Tanzimat dönemine çıkmaktadır. İlk kez, bir öğretmen okulu Darülmuallimin adıyla İstanbul'da, 16 Mart 1848'de tarihinde açılmıştır (Akyüz, 2007; 177).

Türkiye Cumhuriyeti Devletini kurup, hemen ardından Türk toplumunun sosyal, kültürel, politik ve ekonomik yapısına yeni bir şekil ve ruh verenler, bu yeni yapıya uygun, onu yaşatacak yeni nesiller yetiştirecek olan eğitim sistemini kurmayı da ihmal etmemişlerdir. Hatta millî çağdaş ve laik ilkelere dayalı bir eğitim sistemini kurma çalışmalarına cumhuriyet öncesinde, Kurtuluş Savaşı yıllarında başlanılmıştır (Duman,1998;36). Cumhuriyet döneminde de öğretmen yetiştirmeye çok önem verilmiş, bununla ilgili çok daha fazla çalışmalar yapılmıştır. Çünkü 29 Ekim 1923'te Cumhuriyetin ilanı ile ve daha sonra Türkiye'de o zamana kadar görülenlerle karşılaştırılamayacak kadar önemli siyasal, kültürel ve ekonomik değişmeler olmuştur. $\mathrm{Bu}$ gelişme ve değişmelerin kökleşmesinde, kitlelere benimsetilmesinde öğretmenlerin ve eğitimin oynayabileceği rol her zamankinden daha fazla anlaşılmıştır (Akyüz, 1978; 221). 
Köy okulları için öğretmen yetiştirmek amacıyla 1926'da Köy Öğretmen okulları kurulmuş; ancak bunlar verimli çalışma yapamadığından 1932'de kapatılmış ve köy öğretmeni yetiştirmek için yeni modeller aranmaya başlanmıştır (Ergün, 1987; 14). Bu öğretmen ihtiyacını karşılamak için, 1930'lardan itibaren köy eğitmen kursları düşünülmüş ve 1936 yılında deneme niteliğinde ilk eğitmen kursu açılmıştır (YÖK, 2007;30). 1937 yılında da Köy Eğitmenleri Kanunu çıkarılmış ve hemen ardından iki köy öğretmen okulu ile 1940'da çıkarılan Köy Enstitüleri Kanunu ile köye öğretmen yetiştirme sorunu, köklü bir çözüme kavuşturulmuştur (Duman, 1998; 39).

1982 yılına kadar öğretmen yetiştiren yüksek öğrenim kurumları Millî Eğitim Bakanlığına bağlı olup öğrenciler, ögretmenlerinin tavsiyesi dikkate alınarak öğretmende bulunması gereken fiziksel ve kişilik özellikleri yönünden seçilmiştir. 2547 sayılı YÖK kanunun 41. maddesine istinaden bu kurumlar Üniversitelere devredilerek öğretmen yetiştirme yeni bir yap1 ve statüye kavuşmuştur. Bu uygulama öğretmen kaynağı açısından çok önemli bir gelişme olarak kabul edilmektedir.

Öğretmen yetiştirmenin üniversitelere devredilmesinden sonraki süreçte yapı ve programlar bakımından en önemli değişikliğe 1997 yılında gidilmiştir. 1992 y1lından itibaren okul öncesinden yükseköğretime her kademedeki okullar için öğretmen; üniversite çatısı altında eğitim fakültelerinde, 4 yıllık lisans programlarında yetiştirilirken bu tarihte gerçekleştirilen yeni bir düzenlemeyle bazı alanlarda lisansüstüne çıkarılmıştır.

Görüldügü gibi, öğretmen yetiştirme konusu her zaman Türk millî eğitiminin önde gelen sorunlarından biri olmuștur. Zaman zaman köklü çözümler düşünülmüş, öğretmen yetiştiren kuruluşlar oluşturulmuş, bazen de geçici ve acele tedbirlere başvurulmuştur. Nasıl bir öğretmen yetiştirilmek istendiğinin belirli olmadığ yetiştirilmesi konusunda belirli bir politikanın bulunmadığı, buna bağlı olarak da öğretmenlerin niteliğinde giderek belirgin düşmeler olduğu görülmektedir (Akyüz, 2006; 422).

Öğretmen yetiştirmek önemli bir sorundur. Çünkü öğretmen yetiştirmek, yarının insanlarını yetiştirecek olan uzman elemanları yetiştirmek demektir. İnsanlar iyi yetiştirilmeden; daha iyi toplumsal yaşam, daha iyi bir dünya beklenemez. Çünkü yetişmemiş insanlar elinde, en iyi tasarı, plan ve yasalar bile başarısızlığa uğramak durumundadır (Kavcar, 1974; 119). 
İyi bir eğitim sisteminin iyi bir öğretmen yetiştirme sistemine dayanması gerekir. Çünkü öğretmenlerin iyi, nitelikli yetişmesi aynı zamanda onların toplumdaki saygınlık ve statülerini belirleyen ve etkileyen en önemli faktördür. Öğretmenlerin bu yönünü değerlendiren Özdemir, M.Ç. ve Servet Özdemir'e $(1995 ; 161)$ göre; öğretmenliğin statüsünü düşüren faktörler, Türkiye'de çeşitlilik arz etmektedir. Cumhuriyetin ilanından bu güne kadar öğretmen yetiştirmede uygulanan farklı modeller öğretmenleri nitelik açısından ayrıştırmıştır. Siyasal bunalım dönemlerinde öğretmenlerin kendilerine biçtikleri ideolojik rol, sistemin yıpranmasına ve öğretmenlerin statüsünün sarsılmasına neden olmuştur. İşte her yönü ile öğretmen yetiştirme hala önem taşımakta ve güncel olma özelliğini sürdürmektedir. Onun içinde sık sık öğretmen yetiştirme programları da değiştirilmektedir.

\section{2. Öğretmenlerin Sayısal Durumu}

Türkiye'de önemli öğretmen sorunlarından biri de, öğretmenlerin sayısal olarak yeterli olup olmamaları, dengeli dağılımı gibi hususları içeren durumlarıdır. Öğretmenler genellikle sayısal olarak yetersiz kalmışlardır. Eğitim kurumlarının durumu ve ihtiyaç duyulan öğretmen sayısının tespitinde yıllarca sürdürülen ihmaller nedeniyle yeterli sayıda öğretmen yetiştirilememiş, bunun sonucu olarak da ortaya çıkan öğretmen açığının giderilmesinde alan dışından atamalar yapma yoluna gidilmiştir. Bu yanlış uygulamalar, 1860'lardan 2000'li yıllara kadar devam etmiştir.

Öğretmenlerde, sayılarla birlikte nitelik problemi de ortaya çıkmaktadır. Nicelik-nitelik (kemiyet-keyfiyet) sorunu yeni bir sorun olmayıp eğitim tarihinin hemen her döneminde bu tartışma yapılmıştır. Bazı dönemlerde öğretmen yetersizliğinden dolayı sayıya daha çok önem verilmiştir. Böylece niteliksiz ve iyi yetişmemiş öğretmenlerin sistemde yer alması eğitim ve öğretmen sorunlarını olumsuz etkilemiştir (Akyüz, 1978; 314).

Öğretmenlerin sayısal yetersizlikleri ile birlikte ülke genelindeki dağ $111 \mathrm{~m} 1$ da önemli bir sorundur. Öğretmenlerin dağılımı ve sayısal eksiklik gibi çok önemli bir eğitim ve öğretmen sorunun çözümü amacıyla, ölçüsüz, kuralsız bir şekilde ve hiçbir öğretmenlik formasyonu bulunmayanları sisteme dâhil etmek daha büyük eğitimsel sorunların ortaya çıkmasına neden olmuştur.

\section{3. Öğretmenlerin Ekonomik sorunları}

Öğretmenlik mesleğini olumsuz yönde etkileyen, mesleğin saygınlığını ve önemini büyük ölçüde zedeleyen sorunların başında öğretmen maaşlarının yetersizliği gelmektedir. Bu maddi sorun yüzünden öğretmen yetiştiren okullar son sıralarda tercih edilir hâle gelmiştir. Yetenekli kişilerin 
öğretmenlik mesleğini tercih etmemeleri nedeniyle öğretimin niteliği düşmekte ve öğretmenlerin toplumda saygınlığı azalmaktadır. Bu sıkıntıları aşmada, öğretmenin maddi bakımdan imkânlarının yükseltilmesine yönelik her dönemde çeşitli vaatlerde bulunulmuş ve çalışmalar yapilmıştır. $\mathrm{Bu}$ çalışmalarda belirgin ilerlemeler olsa da hâlen, öğretmenlerin ekonomik sıkıntıları en çok sözü edilen husus olmaya devam etmektedir.

\section{4. Öğretmenlerin Hukuki Statüleri}

Öğretmenlerin hukuki statüleri deyince mesleğe atanmalarından başlayarak tayin, terfi, kariyer, saygınlık, itibar, meslekleşme vb. hususlar sayılabilir. $\mathrm{Bu}$ konuda da öğretmenler, yüklendikleri görev ve sorumluluklarla orantılı bir statü elde edememişlerdir.

Toplumda öğretmenlik mesleğinin saygınlık ve itibar görmesi için bazı hususlarında yerine getirilmesi ve önlemlerin alınması gerekmektedir. Akyüz'e göre (2006; 3-5), öğretmenlik mesleğinin saygınlığı oluşturan bazı unsurların var olması gerekmektedir. Bunlar; öğretmenliğin çok önemli bir kamu mesleği olarak kabul edilmesi, meslek okullarının ve meslek ilkelerinin bulunması, mesleğe dışarıdan ilgisiz kişilerin sokulmaması, niteliğin ve niceliğin uygun bir şekilde gözetilmesi, yasal statülerinin düzenlenmesi, ekonomik sorunlarının çözülmesi, öğretmenlerin saygınlığını koruyacak tutum ve davranış sergilemeleri ve öğretmenlerin meslek kuruluşlarının olmasıdır.

Yine öğretmenliğin hukuki statüleri ve öğretmen atamaları konusundaki Cumhuriyet dönemi yasal düzenlemeleri ve uygulamaları değerlendiren Akyüz (2002); 13 Mart 1924 tarih ve 439 sayılı Orta Tedrisat Muallimleri Kanunun 1. maddesinde yer alan; "muallimlik devletin umumi hizmetlerinden talim ve terbiye vazifesini üzerine alan müstakil sınıf ve derecelere ayrılan bir meslektir" ile 22 Mart 1926 tarih ve 789 sayılı "Maarif Teşkilatına Dair Kanun"da da yer alan "maarif hizmetlerinde asıl olan muallimliktir" yasa hükümlerinde, kanun koyucunun, öğretmenliği bir meslek olarak gördüğünü ifade etmektedir. Dolayısıyla eğitim hizmetinde bu meslek mensuplarının önde gelmesi gerektiğini savunmaktadır. Aynı şekilde 1739 sayılı "Milli Eğitim Temel Kanunu" da öğretmenliği "özel bir ihtisas mesleği” olarak tanımlamaktadır.

Bunlardan da anlaşılmaktadır ki, yasa hükümlerine rağmen öğretmenlerin hukuki statüleri güçlü ve belirgin değildir. Sebepleri çok olmakla birlikte ekonomik, yetiştirilme, örgütlenme sorunları ve geldikleri kaynakların çeşitliliği de bu sorunun Osmanlı döneminden beri sürüp gelmektedir. Öğretmenlik mesleğinin saygınlığının korunması ve güçlendirilmesi amacıyla çağın koşullarına uygun bazı hukuki düzenlemelere ihtiyaç olduğu açıç̧a görülmektedir. 


\section{5. Öğretmenlerin Örgütlenme Sorunları}

Öğretmenlerin örgütlenmeleri başlı başına bir öğretmen sorunu olma özelliğini taşımaktadır. Bütün mesleklerde olduğu gibi, öğretmenlik mesleğinde de öğretmen örgütleri bir mensubiyet bilincinin gelişmesi ve meslek saygınlığının oluşması ve güçlendirilmesinde önemli araçlardan biridir. Bu örgütler aracılığıyla öğretmenler mesleki alanlardaki çalışmaları takip ederek kişisel gelişimlerinin sağlanması yanında sosyal ve hukuki statülerindeki iyileştirmelere de olumlu katkılarda bulunabilirler. $\mathrm{Bu}$ açılardan bakıldığında, eğitime ve mensuplarının sorunlarına odaklanmış öğretmen örgütlerine ihtiyaç vardır.

Türkiye'de ilk öğretmen örgütü; Darülfunun ve Darülmuallimin mezunlarının Temmuz 1908 inkılâbından hemen sonra İstanbul da kurdukları "Encümen-i Muallimin”dir (Akyüz; 1971;110). Öğretmenlerin mesleki örgüt kurmaları eski tarihlere rastlasa da örgütlenmeler s1k s1k kesintilere uğramıştır. Öğretmen örgütleri, İkinci Dünya Savaşının sona ermesi ve 1946 yılında demokratikleşme eğilimlerinin yoğunlaştığı bu dönemde 1938 yılında yürürlüğe konan Cemiyetler Kanunu 5.6.1946 tarih ve 4919 sayılı yasa ile değiştirilerek kamu görevlilerine "dernek kurma özgürlüğ̈̈̈"(Altunya, 1998;49) tanınması ile tekrar kurulmaya başlamıştır. Bununla birlikte eski İstanbul Muallimler Birliği yeniden kurulmuştur. Bu öğretmen örgütlerinin sayısı 1948 yılına gelindiğinde 40’1 bulmuştur. Bu örgütlerin amaçları; öğretmen ile devlet arasına girmek, öğretmenlerin dertlerini ve şikâyetlerini idari makamlara iletmek ve bunları sonuca bağlamaya çalışmak olarak belirtilmektedir (Aydın, 1999; 92).

Öğretmenler, sözü edilen değişikliklerden sonra il ve ilçelerde hızla dernekleşmeye başlamış ancak bunlar derneklerin ortak özellikleri ise "dayanışma" örgütü olmaları olmuştur(Altunya,1998). Bu derneklerin tek çatı altında toplanması amacıyla, 1948'de "Öğretmen Yardımlaşma Dernekleri Birliği” kurulmuştur. Bu birlik 1950'de "Türkiye Öğretmen Dernekleri Milli Birliği”, 1954 yılında ise "Türkiye Öğretmen Dernekleri Milli Federasyonu (TÖDMF)" adını almıştır (Altunya, 1998; 56-57).

$\mathrm{Bu}$ örgütler, 12 Eylül 1980 'de yapilan askeri bir darbe ile kapatılmışlardır. 1982 yılından itibaren tekrar kurulmaya başlanmış ve 1985 yılından itibaren de sendikalaşma çabalarına girmişler önce Şubat 1988 'de "Eğitimciler Derneği (EĞİT-DER)"i, 28 Mayıs 1990'da "Eğitim İşkolu Kamu Görevlileri Sendikası (EĞITTIM-İSs)"nı kurmuşlardır. Anılan öğretmen sendikası, 1995'te "Eğitim Bilim ve Kültür Emekçileri Sendikası (EĞİTiMSEN)" ile birleşmiştir (Altunya,1998). Bu alanda, 1992 yılında "Türkiye Eğitim, Öğretim ve Bilim Hizmetleri Kolu Kamu Çalışanları Sendikası 
(TÜRK EĞİTiM-SEN)" ve "Eğitimciler Birliği Sendikası (EĞİTiM BİRSEN)" kurulmuştur. 25.06.2001 tarihinde kabul edilen 4688 sayılı "Kamu Görevlileri Sendikaları Kanunu" ile memurların sendika kurmaları yasal dayanağa kavuşması ile öğretmen sendikaları da bu tarihten sonra tüzel kişilik kazanmışlardır.

Öğretmen örgütlerinin, öğretmenlerin yetiştirilmesi, öğretmenlerin toplumsal ve hukuki statü sorunlarının çözülmesi ve haklarının aranması, aralarında dayanışma ve haberleşme sağlanması, eğitim ve öğretim sahasında mesleki bilgilerin daha rahat alınabilmesi ve verilebilmesi işlevlerini yerine getirebileceği söylenebilir. Yine bunların yanında, öğretmenlerin tayin, terfi, kadro gibi mesleki sorunlarına çözüm araması, kültürel ve mesleki gelişmelerin sağlanması, konferanslar ve seminerler düzenlenebilmesi gibi amaçlara da daha etkili hizmet edebileceği görülmektedir.

\section{6. Öğretmenlerin Mesleki Yayınları}

Öğretmenlerin mesleki yayınları, Bakanlığın yayınladıkları, öğretmen örgütlerinin ve azda olsa bazı öğretmenlerin kendi başlarına çıkardıkları dergiler olarak sayılabilir. Öğretmenlerin mesleki yayın sorunları; ekonomik, hukuki ve örgütlenme sorunlarıyla bağlantıll bir özellik göstermektedir. Ekonomik sorunları çözülmüş öğretmenler, mesleki toplantılara, bilimsel etkinliklere daha çok katılır ve mesleki yayınlara ulaşabilir ve takip edebilirler. $\mathrm{Bu}$ da eğitime ve öğretmenlik mesleğinin niteliğine olumlu katkılar yaptığı gibi öğretmenlerin saygınlığını da artırabileceklerdir.

Buraya kadar sunulan açıklamalar açıkça göstermektedir ki, Türkiye'de öğretmen sorunları, eğitimin temel sorunlarının hem nedeni hem de sonucu olarak değerlendirilebilir. Bu ikilemi aşmanın yolu, öğretmen sorunlarının ivedilikle ve bilimsel yöntemlerle çözülmesidir. Kuşkusuz getirilecek çözümler, kısmi ve günübirlik, geçici değil, bütüncül ve kalıcı olmalıdır. Ögretmen sorunlarının tüm boyutları bilimsel araştırmalarla tespit edilmeli ve yine bilimsel yöntemlerle çözülmelidir.

Öğretmen sorunlarının ele alınıp tartışıldı ğı bilimsel toplantıların başında Millî Eğitim Şûraları gelmektedir. Millî Eğitim Şûraları, Türk Eğitim Sisteminin oluşturulması, geliştirilmesi ve eğitimle ilgili sorunların ele alınıp çözümlerin üretilmesi bakımından çok önemli bir yere sahiptir.

Şûralar, üst düzeydeki yöneticiler, eğitimciler ve araştırmacılar için ayrı bir önem taşımaktadır. Çünkü şûralara, eğitimle ilgili görüşler, düşünceler ve politikalar yansımakta ve toplantılar sonunda sentezlere ulaşılmaktadır. Böylece elde edilen sonuçlar, çoğu kez eğitim politikalarını etkileyecek uygulamalara dönüşmektedir (Duman,1991: 36). 
Millî Eğitim Şûraları, Millî Eğitim Bakanlığı temsilcileri ile bilim adamları, eğitimciler ve eğitimle ilgili diğer kuruluşların temsilcilerinin katıldığı ve Türk Millî Eğitiminin çeşitli sorunlarının ele alınıp tartışıldığı ve çözüm önerilerinin hazırlandığı geniş tabanlı ve bilimsel niteliği bulunan toplantılardır. Cumhuriyet döneminin ilk yıllarından günümüze, çeşitli tarihlerde farklı isimlerle de olsa bu tür toplantılar yapıla gelmiştir. Eğitim sisteminin şekillenmesinde, çağın koşullarına uygun hâle getirilmesinde ve çeşitli eğitim sorunlarının çözümünde bu şûralar çok önemli işlev görmüşlerdir.

Millî Eğitim Şûralarının ilki 1939 yılında toplanmış ve bundan sonra değişik tarihlerde toplanan şûralarda, eğitim ve öğretmen sorunları konusunu sık sık gündeme getirilmiş, döneme göre beliren yeni ihtiyaçlar ve sorunlarla ilgili çeşitli görüşler ileri sürülmüş, öneriler getirilmiş ve uygulanmak üzere bazı kararlar alınmıştır. Bu görüşmeler, tartışmalar, tavsiyeler ve alınan kararlar, zaman zaman öğretmen sorunları ile ilgili politikaları ve uygulamaları etkilemiş, bunların değişmelerine neden olmuştur. Bazen de sadece tavsiye kararları olarak tarihteki yerlerini almışlardır

Millî Eğitim Şûralarında eğitim ve öğretmen sorunları ele alınmış ve değerlendirilmiştir. Şûralarda sunulan birçok öneri öğretmen sorunlarının tespitine ve çözümüne ilişkin olmuştur. Bu çalışmada, 1980-2000 yılları arasında toplanmış olan Millî Eğitim Şûraları ve bu şûralarda ela alınan öğretmen sorunları ile bu sorunlara getirilen çözümler değerlendirilmiştir.

\section{Araştırmanın Amacı;}

$\mathrm{Bu}$ araştırmanın temel amacı, 1980-2000 yılları arasında yapılan Millî Eğitim Şûralarında ele alınan öğretmen sorunları ile bu sorunlara getirilen çözüm önerilerinin uygulamaya yansımalarının değerlendirilmesidir. $\mathrm{Bu}$ amaçla cevaplandırılmaya çalışılan sorular; Türkiye'de 1980-2000 yılları arasında yapılan Millî Eğitim Şûralarında ele alınan başlıca öğretmen sorunları nelerdir? Hangi sorunlar ne ölçüde ele alınmıştır? ve bu Şûralarda ele alınan öğretmen sorunları Millî Eğitim Bakanlığının politika ve uygulamalarına ne kadar yansımıştır? olmuştur.

\section{YÖNTEM}

$\mathrm{Bu}$ araştırma için tarama modeli kullanılmıştır. Tarama modelleri, geçmişte ya da hâlen var olan bir durumu olduğu şekliyle betimlemeyi amaçlayan araştırma yaklaşımlarıdır (Karasar, 2005: 77). Bu araştırma ile Türkiye'de 1980-2000 yılları arasında yapılan Millî Eğitim Şûralarında ele alınan öğretmen sorunları var olduğu şekliyle betimlenmeye çalışılmıştır. $\mathrm{Bu}$ 
haliyle araştırma betimsel düzeyde bir çalışmadır. Betimsel araştırmalar geçmişe dönük yapıldıklarında "ne idi?" yi ortaya koyarlar. Bilimsel çalışmalarda "betimsel araştırma ilk ve temel araştırma eylemidir. Bilginin araştırılmasında ve anlaşılmasında büyük önemi vardır. Eğitim sorunlarının pek çoğu betimsel niteliktedir (Balc1, 2001; 21). Şuralarda yer alan öğretmen sorunları ve bu sorunlara ilişkin çözüm önerileri sırasıyla ve bu araştırma yöntemi ile incelenip değerlendirilmiştir. Bu çalışmada sadece öğretmen sorunlarını direk veya dolaylı olarak ele alan şuralar incelenmiş, diğerleri ise değerlendirme dişında tutulmuştur.

\section{BULGULAR}

\section{A) Millî Eğitim Şûraları ve Öğretmen Yetiştirme Sorunu}

Öğretmen sorunlarının başında gelen öğretmen yetiştirme her zaman güncel olma özelliğini koruyan ve en önemli eğitim sorunlarındandır. $\mathrm{Bu}$ yönüyle öğretmen yetiştirme sorunu, her dönemde çeşitli bilimsel toplantı ve tartışmalara konu olduğu gibi, Millî Eğitim Şûralarına da konu olmuştur.

\section{Onuncu Millî Eğitim Şûrast ve Öğretmen Yetiştirme Sorunu}

Onuncu Millî Eğitim Şûrası, 12 Eylül 1980'de Türk Silahlı Kuvvetlerinin "ülke bütünlüğ̈̈nü korumak, birlik ve beraberliği sağlamak, muhtemel bir iç savaşı ve kardeş kavgasını önlemek, devlet otoritesini ve varlı̆̆ın yeniden tesis etmek ve demokratik düzenin işlemesine mani olan sebepleri ortadan kaldirmak" (Akyüz, 2006: 413) amaciyla yönetime el koyduğu bir döneme rastlayan 23-26 Haziran 1981 tarihleri arasinda toplanmıştır. Türk Silahlı Kuvvetlerinin (TSK) ülke yönetimine el koymasının temel gerekçesi, ülkenin içine sürüklendiği anarşi ve kargaşa ortamının gittikçe içinden çıkılmaz bir hale gelmesiydi. Anarşinin odağında ise genellikle orta ve yükseköğretim öğrencilerinin bulunması, ihtilal hükümetinin öncelikli olarak eğitime eğilmesi sonucunu getirmiştir. Anılan hükümet öncelikle milli eğitim şurasını toplama gereğini duymuştur. İşte Şura, TSK'nin, "Cumhuriyeti Koruma ve Kollama Hareketi" $n$ (Duman,1991) den hemen sonra toplanmış olması da ayrıca bir öneme sahiptir.

"Yeni Türk Millî Eğitim Sistemi" gündemi ile toplanan şûrada, görüşmeler; "Yeni sistemde okul sisteminin yapısı ve sistemin bütünleştirilmesine dönük program modelinin esasları" olmak üzere iki başlık altında yapılmıştır. Bu konuları görüşmek üzere de dört ayrı komisyon oluşturulmuş olup bunlar; "Sistem Komisyonu", "Eğitim Programlar Komisyonu", "Öğrenci Akış Komisyonu" ve "Öğretmen Yetiştirme 
Komisyon"u olmuştur (MEB, 10. Millî Eğitim Şûras1, 1981). Dördüncü komisyonun adından da anlaşılacağı üzere öğretmen yetiştirme sorunu, bu şuranın doğrudan ilgilendiği bir eğitim sorunu olmuştur.

$\mathrm{Bu}$ komisyon raporunda; öğretmen yetiştirmede temel alınması gereken ilkeler belirlenmiş, bu ilkeler doğrultusunda yeni öneri model geliştirilmiştir. $\mathrm{Bu}$ modelin uygulanmasına ilişkinde çeşitli öneriler sunulmuş ve bu modele geçiş için yapılması gereken çalışmalar ele alınmıştır.

Adı geçen komisyon hazırlamış olduğu raporda, öğretmenlik mesleği ve öğretmen yetiştirmede esas olması gereken genel ilkeleri belirlemiştir. $\mathrm{Bu}$ temel ilkeler;

- Ö̆̆retmenlik ve diğer eğitim hizmetlerinin, özel nitelikleri gerektiren bir meslek olmast,

- Bütünlük ve tutarlllık ilkesi,

- Ülke gerçeklerine uygunluk ilkesi,

- Süreklilik ilkesi,

- Öğretmen yetiştirmede yüksek ögrretime dayalılık ilkesi,

- Mesleğin çekici hâle getirilmesi,

- Öğretmen yetiştirme ve ögretmenlerin istihdamında esneklik ilkesi, Kurumlar arası işbirliği ilkesi,

- Özerklik ve demokratiklik ilkesi,

- Öğretmen adaylarının seçimini geniş tabana yayma ilkesi,

- Seçimde ve yetiştirmede uygulama deneyimine ağırlı verilmesi ilkesi,

- Yönetim, denetim, personel, halk eğitimi ve özel eğitim ögrretmenleri ve diğer eğitim personelinin özel olarak yetişstirilmesi ilkesi,

- Öğretmen ve eğitim personelinin akademik ve mesleki çalışmalara katılmalarını kolaylaştırma ilkesi,

- Öğretmen yetiştirmede kredi ve sömestr sisteminin uygulanması ilkesi,

- Öğretmen yetiştiren kurumların bazı özel alanlarda ihtisaslaşmasına ve farklı modelleri denemelerine imkân sağlanması (MEB, 10. Millî Ĕgitim Şûrası, 1981:353-357) olmuştur.

Bu Şûra'da yukarıda sıralanan ilkelerin yanında öğretmen yetiştirmenin farklı üç boyutuna da dikkat çekilmiştir. Öğretmenin, Hizmet öncesi eğitimi, 
Hizmet içi eğitimi ve işbaşında yetiştirilmesi gerektiği belirtilmiştir. Öğretmenin hizmet öncesi eğitiminde; a) öğretmenlik meslek bilgisi, b) Alan Bilgisi ve c) Genel Kültür Bilgisi olmak üzere üç alanda yetiştirilmesi gerektiği de ifade edilmiştir.

Bunun içinde öğretmen yetiştirme model önerileri geliştirilmiştir. $\mathrm{Bu}$ göre; Okulöncesi ve Temel Eğitim birinci ve ikinci kademe kurumlarına öğretmen yetiştirme, ortaöğretim kurumlarına öğretmen yetiştirme sorunu incelenmiştir. Buna göre;

a) Anasınıfı ve temel eğitim birinci kademe (1-5 sınıflar) öğretmenleri yetiştirilmeleri için önerilen model: "Ön Lisans+Öğretmenlik Sertifikası+Bir dönem uygulama",

b) Her kademe öğretmenlerinin yetiştirilmesi için önerilen model ise: "Lisans+Öğretmenlik sertifikası + uygulama" olmalıdır.

$\mathrm{Bu}$ önerilerden sonrada, bu iki modelden hangisine ağırlık verileceğine karar vermek için çeşitli koşulların ayrıntılı olarak incelenmesi, daha geniş seçenekler üzerinde durulması gerektiği uyarıları da yapılmıştır. Söz konusu modelde ayrıca, öğretmen yetiştiren kurumlara öğretmen ve üst düzey eğitim personeli yetiştirme konusu da ele alınmıştır (MEB, 10. Millî Eğitim Şûrası, 1981:353-357).

Yine bu şûrada, öğretmen eğitiminin genel amaçları ele alınmış ve öğretmen yetiştiren bir kurumu bitirerek öğretmenlik formasyonu alan öğrencide bulunması gereken özellikler ayrıntılı olarak sıralanmıştır. $\mathrm{Bu}$ özelliklere bakıldığında Türk Millî Eğitim Sisteminin ihtiyaç duyduğu öğretmen tipinin özelliklerinin ortaya konduğu görülmektedir.

Raporda, öğretmenlik meslek bilgisi derslerinin yanında, ihtiyaca ya da amaca uygun olarak seçmeli derslerin açılabileceği ve bu derslerden 2 ya da 3'nü öğrencinin alması önerilmiştir. Bu dersler; mesleki ve teknik öğretimin esasları, teknik öğretim programları, tarım eğitimi programları, ticaret eğitimi programları, rehberlik, öğretmen ve dünya sorunları, özel eğitim gibi olabilecektir.

Bunlarla birlikte şûrada, önerilen modele uygun öğretmen yetiştirmede uyulması gereken temel esaslar belirlenmiştir. Bu temel esaslardan bazıları şöyledir:

1. Öğretmenler çok boyutlu yetiştirilmeli, en az bir esas alan ve bir yan alan olmak üzere iki alanın öğreticiliğini yapabilmelidir.

2. Öğretmenlerin yurt ölçüsünde dengeli dağılımı sağlanmalıdır. 
3. Öğretmen yetiştirme programlarında bütünleşmeye gidilmelidir.

4. Öğretmen yetiştiren kurum öğretmenleri akademik kariyer sahibi olmalidir.

5. Koşullar zorlamadı̆̆ takdirde öğretmenlerin hizmet öncesi eğitimleri mümkün olduğu kadar yukarlya çekilmeli, hatta öğretmenlerin yüksek lisans ve doktora yapmalarına olanak sağlanmalıdır.

6. Öğretmen yetiştirme uzmanlık programlarında standart bir birlik sağlanmalı ve bu standart üniversite programları düzeyinde olmalıdır.

7. Ögrretmen ve uzman yetiştirmede hem kalite hem saylsal sorunlar birlikte düşünülmelidir.

8. Öğretmen ve uzman yetiştirme programlarında yenileşmeye gidilirken sorun, programlara ders ekleyip çıkarma gibi kısır bir yaklaşımla ele alınmamalıdir.

9. Mevcut öğretmenleri ve uzmanları yeni sisteme uyarlayabilmek için derhal hizmet içi eğitim programları açılmalıdır.

10. Yetiştirme programlarının etkin olabilmesi için gerçek ihtiyaçları karşılayacak derinlemesine araştırmalar yapılmalıdır (MEB, 10. Millî Eğitim Şûras1, 1981: 96-97).

$\mathrm{Bu}$ temel ilkelere bakıldığında, öğretmen yetiştirmenin esasları yanında mesleğin diğer sorunlarının da dikkate alındığı görülmektedir. Nitelik ve nicelik, dengeli dağılım, programların standartlaştırılması gibi sorunlara da işaret edilmiştir.

Yine bu şûrada "Mevcut Öğretmenlerin Modele Uyarlanması" ile ilgili önerilere ve yapılması gerekenlere de yer verilmiştir. Ayrıca hizmet içi eğitimden geçirilmesi gereken öğretmen sayısının çokluğu, komisyonu geleneksel hizmet içi eğitim yöntemlerinin dışında, yeni bir yaklaşım aramaya götürmüştür. Bunlar arasında; yeni hizmet içi eğitim merkezlerinin kurulmas1, ders ve kaynak kitapların hazırlanması, bu kitapların yeterli miktarda bastırılması, öğretmenlerden belli bir süre içinde bu kitapları çalışarak kendilerini yetiştirmelerinin istenmesi sayılmıştır. Yine belirtilen bu süre sonunda öğretmenlerin hizmet içi eğitim merkezlerince düzenlenecek sınavlara tabi tutulmaları ve başarılı olanların bu merkezlerde 8-10 haftalık bir eğitimden geçirilmeleri, bu eğitimin sonunda yapılacak sınavlarda başarılı olanlara, "yeterlilik sertifikası" verilmesi, başaramayanlara ise öğretmenlik yapma izni verilmemelidir. Son olarak da "önerilen öğretmen yetiştirme modelinin uygulamaya aktarılması için yapılması gereken çalışmalar" yer almış ve önerilerin uygulamaya 
aktarılması için, öncelikle hazırlık çalışmalarının yapılması ve modelin uygulanmasında kademeli bir yaklaşımın izlenmesi kararlaştırılmıştır.

Sonuç olarak, 10. Millî Eğitim Şûrası'nda ele alınan öğretmen yetiştirme modelinde; okulöncesi, ilköğretim ve ortaöğretim kademelerine öğretmen yetiştirilmesinin ele alındığ 1 görülmektedir. Yine bu Şûra'da bir eğitim sisteminin en önemli öğelerini, öğretmenler ve diğer eğitim personelin oluşturduğunun söylenmiş olmasının öğretmenlik mesleği açısından ayrı bir önemi vardır.

\section{Onbirinci Millî Eğitim Şûrası ve Öğretmen Yetiştirme sorunu}

11. Millî Eğitim Şûrası, 8-11 Haziran 1982 tarihleri arasında "Millî Eğitim Hizmetinde Öğretmen ve Eğitim Uzmanları (Durum ve Sorunlar)" konulu gündemle toplanmış ve çalışmalar yapmıştır. Bu Şura tamamen öğretmen ve eğitim uzmanlarını konu edinmesinden dolayı ayrı bir değer taşımaktadır. Şûrada öğretmen yetiştirme sorunu üzerinde yoğunlaşılmış ve öğretmenin en iyi biçimde nasıl yetiştirilmesi gerektiği ayrıntılı bir şekilde incelenmiştir.

Şûrada, öğretmen eğitiminin tarihsel gelişimi, Cumhuriyet öncesi dönemde öğretmen eğitimi, Cumhuriyet dönemi öğretmen eğitimi ve öğretmen yetiştirme ile ilgili politika, eğilim, amaç ve ilkeler tartışılmış, öğretmen yetiştiren kurumların gelişimi, bu günkü durumları ve öğretmenlerin hizmet içi eğitimleri incelenmiştir. Yine çeşitli ülkelerde öğretmen yetiştirme modelleri inceleme konusu edilmiş, mevcut öğretmen yetiştirme sistemine ilişkin sorunlar tartışılmış ve öğretmenlik mesleğinin genel standartları belirlenmiştir. Ayrıca modelin başarı koşulları ve uygulama önerileri ele alınmıştır.

Bunların yanında bu şûrada, öğretmen eğitiminin genel amaçları ve öğretmen yetiştiren bir yükseköğretim kurumunu bitiren öğrenci de bulunması gereken temel nitelikler belirlenmiş, yapılan tartışmaların ana eksenini, öğretmenlerin nerede, hangi kurum tarafindan eğitilmesinin, amaçlar açısından daha uygun olacağ 1 konusu tartışılmıştır. Bu konuda üniversiteler ve MEB'i öne çıkaran iki farklı görüş ortaya çıkmıştır. İki görüş sahiplerinin de kendilerine göre önemli gerekçeleri ve haklılıkları bulunmakla birlikte, YÖK'ün MEB ile eşgüdüm içerisinde öğretmen yetiştirme işini üstlenmesinin daha doğru olacağı, her iki tarafinda kaygılarını giderici ortak bir görüş olarak kabul edilmiştir. Böylece öğretmen yetiştiren tüm kurumların YÖK'e devredilmesi ve öğretmen kaynağının birleştirilmesi görüşü şûra kararı olarak benimsenmiştir. 
İşte bu şuradan sonra, Millî Eğitim Bakanlığına bağlı olarak faaliyet gösteren ve öğretmen yetiştiren bütün yüksekokul ve enstitüler, 2547 sayılı YÖK Kanununa istinaden çıkarılan 41 sayılı Kanun Hükmünde Kararname ile 1982'de Üniversitelerin bünyesine alınmıştır. Bu kanundan sonra her kademede öğretmen yetiştirme süresinin 4 yıla çıkarılması uygulaması da başlamıştır.

Öğretmen yetiştiren Fakülte, Yüksekokul ve birimlerine öğrenci alımında, programların oluşturulmasında ve öğretim elemanı yetiştirilmesinde -özellikle geçiş döneminde- üniversiteler ile MEB'in yakın işbirliği içinde bulunmaları zorunlu görülmüş ve buralara öğrenci alımında, öğretmen liseleri ve diğer okullara belirli oranda kontenjan tanınması istenmiştir. Öğretmen ihtiyacını karşılamak üzere gerekli görülen alanlarda lisans öğrenimini tamamlayanların Eğitim Fakültelerinde Pedagojik Formasyon görmek suretiyle öğretmen olarak atanabilecekleri kararlaştırılmıştır.

Şûrada ayrıca öğretmenlerin yetiştirilmesi sürecinde karşılaşılan çeşitli sorunlar, olumsuzluklar da gündeme getirilerek tartışılmıştır. Aynı şûrada, bir yıl önce toplanmış olan Onuncu Millî Eğitim Şûrası'nda alınan kararlar doğrultusunda yeni bir öğretmen yetiştirme modeli önerilmiş ve bu modele ilişkin yeni esaslar da belirlenmiştir. Önerilen bu modele göre yeni esasları şöyle sıralanmıştır:

- Hangi kademe için hazırlanırsa hazırlansın öğretmen adayının lise üstü bir ögretim görmesi gerekmektedir.

- Var olan yasal esas ögrretmen yetiştirme sürelerini kayda bağlamamaktadır. Geliştirilen modele göre her kademe ögretmenliği için genel kültür, alan bilgisi ve meslek bilgisi dâhil lisans (4 yıllık ögrenim) düzeyinde olmalıdır.

- $\quad$ Nitelik sorununun çözümüne kadar sürenin nasıl kullanılacă̆ konusu da büyük önem taşır. Her kademe öğretmenliğinin gerektirdiği bilgi ve beceriler bu süre içinde en iyi bir biçimde kazandırılmalıdır (MEB, 11. Millî Ĕgitim Şûrası, 1982: 73-77).

Ayrıca, bu şûra da öğretmen eğitim programlarının bütünleştirilmesi ilke olarak kabul edilmiş ve öğretmen yetiştirme programlarında da bütünleşmeye gitmek gerektiği vurgulanmıştır. Öğretmen yetiştirme programlarının bütünleştirilmesi ile birlikte öğretmen adayının göreceği eğitimin yatay ve dikey geçişlere olanak sağlayacak biçimde düzenlenmesi ve her adayın esas alanın yanında bir de yardımcı alanda yetiştirilmesi de kararlarda yer almıştır (MEB, 11. Millî Eğitim Şûras1, 1982). 
Şurada, öğretmen yetiştirme programlarında “İçerik Kategorileri”nin düzeni ve ağırlığı da belirtilmiş, öğretmen olacak bir kişinin mutlaka; "öğretmenlik meslek bilgisi”, "alan bilgisi” ve "genel kültür bilgisi”ne sahip olması gerektiği vurgulanmış ve bunlar karar haline getirilmiştir.

Ayrıca sözü edilen bu içerik kategorilerinin öğretmen yetiştirme programlarındaki yeri nasıl olacaktır? sorusunun cevabı aranmış, programların içerik boyutları ve düzeni de tartışılarak karara bağlanmıştır. $\mathrm{Bu}$ önerilen modele göre içerik kategorileri şekil 1 'deki gibi düzenlenmiştir.

Şekil 1. Öğretmen Yetiştirme Programlarında Muhteva Kategorileri ve İçerikleri.

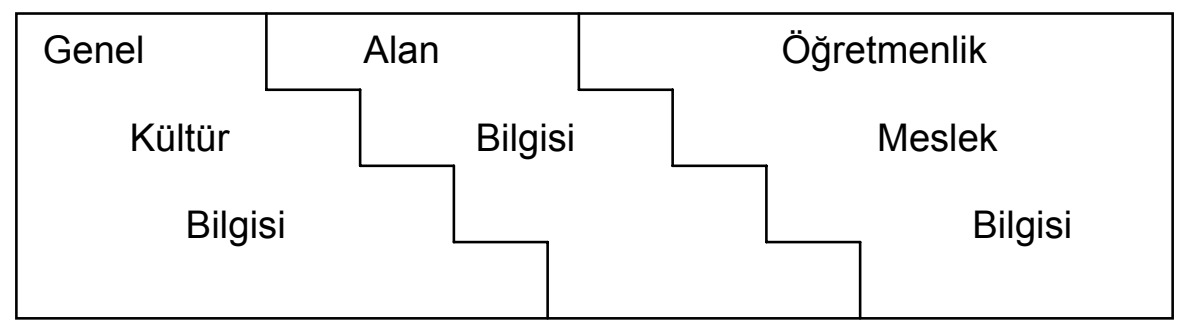

4. $\mathrm{y} 11$

3. y1l

2.y1

1.y1

Kaynak: MEB, 11. Milli Eğitim Şurası, 1982; s. 69.

Bu düzenlemede, öğretmen yetiştirmede her üç muhteva kategorisi tüm sınıflarda paralel bir biçimde okutulmaktadır. Şekilde görüldüğü gibi öğretim yılları ilerledikçe; Alan Bilgisi ağırlığını korurken Genel Kültür Bilgisi gittikçe azalmakta, Öğretmenlik Meslek Bilgisi ise artmaktadır.

Öğretmen yetiştiren kurumların programları için model oluştururken, içerik kategorilerinin ağırlığının titizlikle saptanması gerektiği üzerinde durulmuştur. Özellikle temel ve ortaöğretime öğretmen yetiştirme modelindeki muhteva kategorilerinin ağırlığ belirlemeler yapılmıştır. Buna göre; Alan Bilgisi \% 62,5, Öğretmenlik Meslek Bilgisi \% 25,0 ve Genel Kültür Bilgisi \% 12,5 olması gerektiği kararı alınmıştır.

$\mathrm{Bu}$ modelin her tür öğretmen yetiştirme programı için kesin bir ölçüt olmakla birlikte muhteva kategorilerinin ağırlığı saptanırken öğretmen adayının görev yapacağ 1 okul kademesi ve tipinden beklenen bilgi ve 
becerilerin göz önüne alınması, esas olanın tüm adaylara öğretmenlik davranışı kazandırmak olduğunun unutulmaması gerektiği de kararda yer almıştır.

$\mathrm{Bu}$ önerilen modele göre oluşturulacak kurum programlarının amaçları, işlevleri, ilkeleri, içerik ve etkinlik kademeleri çeşitli eğitim kademelerine göre ayrı ayrı belirlenmiştir. Şura'da bunların yanı sıra, "Öğretmen Yetiştiren Öğretmenlerin Yetiştirilmesi" de ayrı bir başlık altında değerlendirilmiş ve bunun için de bir program önerilmiştir. Bu programının başarı koşulları ve uygulama için öneriler; programlara, öğretim kadrosuna, öğrenci seçimine ve diğer konulara ilişkin olmuştur.

Yine bu şurada öğretmenlik mesleğinin saygınlığını koruma amacıyla mesleğe girişte sadece üniversite giriş sistemindeki seçme esasları ile yetinilmeyip mesleğe yatkınlık ve bağl1lık açılarından da öğretmen adaylarının başka seçmelere tabi tutulması önerisi ile birlikte öğretmen yetiştiren kurumların siyasal iktidarların müdahalelerine açık oluşu gerçeği dile getirilmiştir. Bunun için dikkate değer ve bir o kadar da önemli olan, her türlü siyasal müdahaleye engel olabilecek yeni bir öğretmen yetiştirme programının geliştirilip uygulamaya konulması önerisi yapılmıştır.

\section{Onikinci Millî Ĕ̆itim Şûrası ve Öğretmen Yetiştirilmesi Sorunu}

Öğretmen yetiştirme sorunu, 18-22 Temmuz 1988 tarihleri arasında toplanan 12. Millî Eğitim Şûrasında da ele alınan konulardan birisi olmuştur. Bu Şûra'da, Türk eğitim sistemi, yüksek öğretim, öğretmen yetiştirme, eğitimde yeni teknolojiler, Türkçe ve yabancı dil öğretimi, eğitim finansmanı ve öğretim programları gibi birçok konu gündeme alınmış ve ilgili komisyonlarda görüşülmüştür. Bu konular içerisinde öğretmen yetiştirmeye yönelik tartışma ve getirilen öneriler önemli bir yer tutmuştur. Ancak görüşme ve tartışmalar daha ziyade, teknolojik gelişmelerin öğretmen eğitiminde daha ağırlıklı olarak yararlanılması üzerinde yoğunlaşmıştır.

Öğretmen Yetiştirme Komisyonu Raporu'nun giriş bölümünde, toplumsal ve teknolojik gelişmelere değinilmiş ve bunun da eğitim kurumlarını etkilediği belirtilmiştir. Öğretmenin, eğitimin en önemli unsuru olduğu ve teknolojik gelişmelerin öğretmenin rolündeki beklentileri de önemli ölçüde etkilediği vurgulanmıştır. Söz konusu raporda yer alan mevcut durumun değerlendirilmesi yapılmış; toplumun mimarları olan öğretmenlerin hâlen mesleki bilgi ve becerilerinin, çağın ihtiyaçlarına cevap verecek seviyede olmadığı, oysa yurdun kalkınması ve milletin refah ve saadeti, öğretmenlerin iyi yetiştirilmesine ve görevlerini en iyi şekilde yerine getirmesine bağlı olduğu ifade edilmiş̧ir. Öğretmenlik mesleğinin, bir 
milletin kaderini tayin eden bir meslek (MEB, 12. Millî Eğitim Şûrası, 1988) olduğu vurgusu da yapılmıştır.

Şuarada, öğretmenlerin hizmet öncesi yetiştirilmesi, eğitim-öğretim programları, öğretmen yetiştiren yükseköğretim kurumlarına öğretim elemanı sağlanması ve yetiştirilmesi konuları ayrıntılı olarak ele alınmıştır. $\mathrm{Bu}$ konular üzerinde uzun müzakereler yapıldıktan sonra öğretmen yetiştirme ile ilgili önemli kararlar alınmış olup, bu kararlardan bazıları;

- Okulöncesi ĕgitim kademesine (anaokulu ve anasinıfi) öğretmen yetiştiren yüksekögretim programlarının öğretmen lisesi mezunlarının belli kontenjan, puan avantajı sağlanmış ÖSS puanıyla, meslek lisesi mezunlarının ise ÖSS mesleğe yatkınlık testi ile alınmalarl, bu programların Eğitim Yüksekokulları bünyesinde düşünülmesi,

- Eğitim Yüksekokullarının dört yıla çıkarılması ve sinıf ögretmenliği anabilim dalına ögretmen lisesi mezunlarının belli bir kontenjan ve puan avantajı sağlanmış ÖSS puanı ile alınmaları,

- Eğitim Yüksekokullarında sınıf öğretmenliği yanında, Temel eğitim ikinci devresinde veya ortaokullara Fen Bilgisi, Sosyal Bilgiler, Türkçe, Matematik gibi branş öğretmeni yetiştiren bölümlerin açılması ve bu bölümlere ögretmen lisesi mezunlarının belli kontenjan ve puan avantajı sağlanmış ÖYS puanı ile alınmaları,

- Eğitim Yüksekokulu öğrencilerinin (sınıf öğretmeni adayları) ögretmenlik uygulamalarının bir kısmını, mutlaka köy ilkokullarında yapmalarının sağlanması karar altına alınmıştır.

- Bakanlık Merkez teşkilatında "Öğretmen Eğitimi Genel Müdürlüğ̈̈nün” kurulması (MEB, 12. Millî Eğitim Şûrası,1988: 363-367) olmuştur.

Bu Şuradan sonra Bakanlık merkez teşkilatında yer alan "Öğretmen Eğitimi Genel Müdürlüğünün” kurulması gerçekleşmiştir. Ayrıca, öğretmenlik mesleğini yüceltmek, cazibesini arttırarak, başarılı ve yetenekli öğrencilerin bu mesleğe yönlendirilmelerini sağlamak amacıyla üniversite giriş sınavlarındaki ilk 10 tercih arasında, öğretmen yetiştiren programlara yer verip kazanan öğrencilere burs, yatılılık imkânı veren 15 Haziran 1989 tarih ve 3580 sayılı kanun çıkarılmıştır. Böylece söz konusu şûrada alınan çok önemli kararlardan en azından bir kısmı uygulamaya konabilmiştir.

\section{Ondördüncü Millî Ĕ̆itim Şûrası ve Öğretmen Yetişstirilmesi Sorunu}

14. Millî Eğitim Şûrası, 27 - 29 Eylül 1993 tarihleri arasında toplanmıştır. Bu Şûrada; "Eğitim Yönetimi ve Eğitim Yöneticiliği ile Okul 
Öncesi Eğitimi” konuları görüşülmüştür. Okul Öncesi Eğitimle ile ilgili genel görüşmelerde bu alana öğretmen yetiştirmeye ilişkin kararlar alınmıştır. Burada; "Okul Öncesi Eğitim Kurumlarına Öğretmen Yetiştirme, Okul Öncesi Eğitim Kurumlarında Görev Alacak Öğretmenlerin Özellikleri, Okul Öncesi Eğitim Kurumlarına Öğretmen Yetiştirmede Karşılaşılan Sorunlar" gibi önemli konular ele alınmış ve her birine ilişkin çeşitli öneriler getirilmiştir.

Şûrada, Okul Öncesi eğitimin önemine vurgu yapılarak bu kurumlarda görev alacak öğretmenlerin sahip olması gereken nitelikler konusunda ayrıntılı olarak belirlemeler yapılmıştır. Bu belirlemelerde, öğretmenlik için gerekli niteliklerin yanında, ögretmenin hitap edeceği kitle açısından da öne çıkarılan özellikler de yer almıştır. Buna göre, söz konusu kurumlarda görev yapacak bir öğretmende aranan nitelikler şunlar olmalıdır:

1. Türk Millî Eğitimi'nin amaçlarını, görev aldı̆̆ı okulun amaçlarını, toplumun ve bu yaş grubu çocuğunun ihtiyaçlarını bilir,

2. İyi bir genel kültür ve bunun yanında çok iyi bir mesleki bilgiye sahiptir,

3. Bu yaş grubu çocuklarının gelişim özellikleri ile ihtiyaçlarını dikkate alarak tüm gelişimlerine katkıda bulunur, çocukları tanıma ve yöneltme teknik ve usullerini bilir,

4. Eğitimde araç-gereç kullanma ve yapma becerisine sahiptir,

5. Fen ve güzel sanatlar alanlarında bilgi ve becerilere sahiptir,

6. Belli alanlarda yetenekli çocukların ilgileri doğrultusunda gelişmeleri için rehberlik eder. Özel eğitime muhtaç çocukları belirler ve bunların eğitimleri için ilgililerle iş birliği yapar,

7. Okul Öncesi çocuklarının gelecekte yapıcı, yaratıcl, medeni cesaret sahibi, çalışmayı ve iş başarmayı seven, araştırıcı bireyler olması konusunda yol gösterir,

8. Ailelerle, diğer Okul Öncesi öğretmenleriyle, ilkokul öğretmenleri ile işbirliği yapar,

9. Ruh ve beden sağliğg yerindedir ve çocuklar için davranış modelleri oluşturur,

10. Türkçeyi doğru ve güzel konuşur ve yazar,

11. Çocukların gelişsiminin iyi bir şekilde olması için beslenme, sağllk bilgisi ve ilk yardim bilgi ve becerilerine sahiptir.

12. Güncel olaylarl izler, sürekli ögrenmeye ve kendini geliştirmeye açıtktır(MEB, 14. Millî Eğitim Şûrası, 1993:257-258).

Burada sözü edilen bazı niteliklerden anlaşıldığı gibi okul öncesi eğitim kurumlarına, öğretmenlik formasyonu ve niteliği kazanmış vasıflı öğreticilere ihtiyaç duyulmaktadır. Bunlarla birlikte, okulöncesi öğretimin önemi her geçen gün daha iyi anlaşılmasına ve bu kurumlarda görev yapacak 
öğretmenlerin yetiştirilmesi üzerinde daha bir özenle durulmasına rağmen, bu konuda tam bir eylem birliği sağlanamamış olduğu ifade edilmiştir. $\mathrm{Bu}$ dönemde bu amaçla çeşitli üniversitelerde farklı programlarla öğretmen yetiştirilmektedir. Örneğin; Gazi, Marmara, Selçuk ve Karadeniz Teknik Üniversitelerinde okul öncesine öğretmen yetiştirilmektedir. Ancak bu üniversitelerdeki uygulanan programlar arasında farklılıklar bulunmaktadır.

Okulöncesi eğitim kurumlarına öğretmen yetiştirme de var olan sorunlarda tespit edilmiştir. Öğretim süresinin lisans düzeyine çıkarılması gerektiği belirtilmiş ve öncelikle üniversite giriş sınavlarına katılan genel lise mezunlarının, öğrenimlerini bu alandaki meslek liselerinde tamamlayan öğrencilerin yüksek öğrenim görme şansını azalttığı, bununda eğitimin kalitesini olumsuz etkilediği vurgulanmıştır. Öğretmen adaylarının bu sınavların yanında sözlü sınavdan geçirilmesi istenmiştir. Mülakattan geçirilmeyen öğrencilerin fiziksel ve hatta ruhsal yönden öğretmenliğe uygun olmayanlarının bulunduğu iddia edilmiştir. Ayrıca yüksek öğrenim, uygulama ve iş alanları arasında kopukluğun olduğu, öğretmen yetiştiren fakülte ve yüksek okullarda, öğrenci sayısının fazlalığı nedeniyle uygulamalı eğitime firsat bulunamadığ 1 ve okul öncesi öğretmenlerinin hizmet içi eğitimden mahrum kaldığ da (MEB, 14. Milli Eğitim Şurası,1993:268-269) belirtilmiştir. Sıralanan bu endişelerin ve olumsuzlukların aşılmasında yeni düzenlemelere ihtiyaç vardır. Ancak düzenlemelerin yeni sorunlara yol açmaması gerekmektedir.

Şûrada, okul öncesi eğitimi için öğretmen adayının seçiminden yetiştirilmesine ve istihdamına kadar bir dizi öneri sunulmuştur. Aslında bu öneriler, öğretmen yetiştirmeye yönelik genel öneriler olup öğretmenlik mesleğinin tanıtımı için MEB'in diğer kurum ve kuruluşlarla işbirliği yapmas1, bu alanda yetiştirilecek öğrencilerin seçimi, fakülteler ve programlar arasındaki işbirliği ve paralellikler kurulmasına ilişkin öneriler önemli bir yer tutmuştur. Bu öğretmen yetiştirmede karşılaş1lan güçlüklerin aşılmasında öngörülen yöntemlerden birinin yine hizmet içi eğitim olduğu da belirtilmiştir. Yine bu önerilere bakıldığında, okul öncesi eğitimin yaygınlaştırılması, geliştirilmesi, bu kurumlarda görev yapacak öğretmenlerin yetiştirilmesinde kurumlar arasında ortak bir tutumun sağlanması da görülmektedir.

Şurada sunulan öneriler daha sonra tavsiye kararlar hâline dönüştürülmüştür. Tavsiye niteliğinde ki kararlarda, okul öncesi eğitim kurumlarına öğrenci seçiminden, öğretmen eğitimine kadar pek çok soruna ve bunların çözüm yollarına işaret edilmiştir. Okulöncesine nitelikli öğretmen yetiştirmek için; ortaöğretim kurumlarında mesleki rehberlik hizmetlerine ağırlık verilerek okulöncesi öğretmenliğine istekli ve nitelikli 
öğrencilerin yönlendirilmesinin sağlanması, öğretmen yetiştiren yüksek öğretim kurumlarındaki çocuk gelişimi ve eğitimi öğretmenliği programı ile anaokulu öğretmenliği programının birbirinden ayrılması ve bu fakültelerin bünyelerinde uygulama anaokulları açılması kararlaştırılmıştır. Ayrıca yeterli öğretim elemanı, personel ve gerekli diğer imkânlara sahip olan yüksek öğretim kurumlarına anaokulu öğretmenliği açma izninin verilmesi, bu kurumlarda görev alacak personelin görev analizlerinin yapılması ve okulöncesi öğretmenlerinin lisansüstü eğitim yapmalarına imkân sağlanması (MEB, 14. Millî Eğitim Şûras1,1993: 261-323) gibi önemli kararlar yer almıştır.

$\mathrm{Bu}$ kararlarda söz konusu kurumların öğretim kadrolarının da yetiştirilmesi ve güçlendirilmesi hedeflenmiş olmakla birlikte Türkiye'de okulöncesi eğitiminin geliştirilmesi ve yaygınlaştırılması amacının da güdüldüğü görülmektedir.

\section{Onaltıncı Millî Ĕğitim Şûrası ve Öğretmen Yetiştirilmesi Sorunu}

"Cumhuriyetimizin 75. Yılında Mesleki ve Teknik Eğitim” gündemiyle 22-26 Şubat 1999 tarihlerinde toplanan 16. Millî eğitim şûrasında tartışılan konular arasında öğretmen yetiştirme sorunu önemli bir yer tutmuştur. $\mathrm{Bu}$ şurada, "öğretmen ve yönetici yetiştirme" sorunu; Mesleki ve Teknik Eğitim Alanına Öğretmen ve Yönetici Yetiştirme Komisyonunda ele alınmıştır. Komisyon raporunda öncelikle, mevcut durum ve sorunlar ele alınmış, sorunların çözümüne ilişkin öneriler sunulmuştur.

Raporda, mevcut duruma ilişkin yapılan değerlendirmelere göre; mesleki ve teknik eğitimde görev yapmak üzere yetiştirilecek öğretmen adayları, mesleki ve teknik ile genel orta öğretim kurumları öğrencilerinin tercihleri doğrultusunda, mesleklerin özelliklerine göre, ilgili programlardan gelenlere ek puan uygulanarak, farklı puan grupları ile ÖSYM'ce yapılan Seçme ve Yerleştirme sınavı sonucunda seçilmektedir. Ancak mesleki ve teknik eğitim ile genel orta öğretim kurumlarına mesleki rehberlik ve danışmanlık hizmetleri istenilen düzeyde sunulmamaktadır. Bu durum yönlendirme açısından istenmeyen sonuçlar doğurmaktadır. Mesleki ve teknik eğitim fakültelerine alınacak öğrencilerin sayısının belirlenmesinde, Bakanlığın nicelik ve nitelik olarak duyduğu öğretmen ihtiyacı göz önüne alınmamaktadır. Zaman zaman Mesleki ve teknik öğretmen yetiştirme konusunda Bakanlık-YÖK arasında işbirliği ve koordinasyon çalışmaları yapılmakla birlikte söz konusu işbirliği ve koordinasyon, arz - talep dengesini kurmaya yetmemektedir (MEB, 16. Millî Eğitim Şûrası:1999). Bunlar, gerek seçmede ve gerekse yönlendirmede bazı sorunlar sebep olmaktadır. Şuarada bu sorunlara ilişkin bazı tespitler yapılmıştır. Buna göre; 
- Orta öğretimde, öğrencilere yeterli bir mesleki rehberlik hizmeti verilememektedir,

- Öğretmenlik programlarının çeşidi ve öğrenci sayıları, insan gücü ihtiyaçları ile uyumlu değildir.

- Öğrenciler, öğretmenlik programlarına tercih sıralamasında son siralarda yer vermektedir.

- Birçok alanda arz fazlası öğretmen mevcuttur. Buna karşılık bazı alanlarda da talep karşılanamamaktadır. Talebin karşılanamadığ 1 kurumlar ihtiyaçlarını istenilen niteliklere yeterince sahip olmayan kişilerle karşılamaya çalışmaktadır. Arz fazlası öğretmenler de değerlendirilememekte ve bunlar sisteme yük olmaktadır (MEB, 16. Millî Eğitim Şûras1,1999; 265-266).

Bunlardan da anlaşıldığ gibi bir planlamanın yapılmadığ 1 ve belli bir programın izlenmediği görülmektedir. Burada gündeme getirilen seçme ve yönlendirmeye ilişkin sorunlar nedenleriyle irdelenmiş ve her birisinin çözümüne ilişkin çok sayıda öneri ortaya konmuştur. $\mathrm{Bu}$ sorunların çözümüne ilişkin önerilerden bazıları ise;

- Öğretmenlik mesleğini özendirmek amacıyla, programların genel orta ögretim mezunlarına da açık tutulmasına devam edilmesi,

- Öğrencilerin seçiminde, ilgili alan öğretmenliğinin gerektirdiği beceri ve yetenek sınav1, ilgili mesleki ve teknik eğitim fakültelerince yapilması,

- Öğretmenlik mesleğini seçeceklerin mesleğin gereklerini yerine getirmelerine engel bir özürleri bulunmaması,

- Mesleki ve Teknik Liselerde görev yapacak öğretmenlerin, ilgili alanlarda meslek yüksek okullarını başarıyla bitirenler arasından, mesleki ve teknik eğitim fakültelerine dikey geçiş yaparak yetiştirilmelerinin teşvik edilmesi (MEB, 16. Millî Eğitim Şûrası, 1999) olarak belirlenmiştir.

$\mathrm{Bu}$ önerilerde özendirme, planlama, seçme esasları ve alanda uzmanlaşmayı sağlamaya yönelik çözüm arayışları bulunduğu görülmektedir. Gerek nitelik ve gerekse nicelik açısından eksiklerin giderilmesinde bu çözüm önerilerin etkili olacağı düşünülmüştür. $\mathrm{Bu}$ önerilerin önemli, makul ve kabul edilir olduğu görülmekte ancak bunların uygulamaya yansıması gerektiğine hiç şüphe yoktur. 
Bu mevcut durumdan kaynaklanan bazı önemli sorunların ortaya çıkmış olduğu belirtildikten sonra bu alan için öğretmenlerin yetiştirilmesinde yaşanan sorunlardan bazıları şöyledir:

- Öğretmenlik alanlarının tanımı yapılmamış ve nitelikleri belirlenmemiştir.

- Mesleki ve teknik eğitimde, nitelik ve nicelik olarak ihtiyaç duyulan bütün alanlarda öğretmen yetiştirilmemektedir. Mesleki ve teknik eğitim fakültelerinin öğretmenlik programları ile mesleki ve teknik okulların programları arasında uyumsuzluklar vardır.

- Eğitim fakültelerinde eğitim daha çok teorik olarak yürütülmekte, kurum içinde veya dışında yeteri kadar uygulama yaptırılmamaktadır.

- Mesleki ve Teknik Eğitim Fakülteleri, bina, araç, gereç ve kadro yönünden yetersizdir. Buna rağmen öğrenci kapasitesi giderek artırılmaktadır.

- $\mathrm{Bu}$ kurumlara öğretim üyesi temininde ve yetiştirilmesinde güçlük çekilmektedir.

- Orta ve yüksek öğretim kurumlarının programları, birbiriyle ve iş hayatıyla uyumlu değildir.

- Mesleki ve teknik eğitim fakülteleri mezunlarını izleme çalışmaları yapılmamaktadır.

- İhtiyaç belirlenmeden, gerekli alt yapı hazırlanmadan ve çevre şartları dikkate alınmadan gelişi güzel teknik eğitim fakülteleri açılmaktadır (MEB, 16. Millî Eğitim Şûrası, 1999: 270- 272).

İşte bu mevcut durum ve uygulamaların sebep olduğu bu sorunların ortadan kaldırılmasına ve çözüme kavuşturulmasına dönük bazı öneriler de getirilmiştir. Ancak sunulan öneriler, genellikle mevcut uygulamaların doğurduğu sorunları gidermeye yönelik olduğu görülmektedir. Yine bu öneriler önemli ölçüde tavsiye kararlarına dönüştürülmüş ve bunlara istinaden birçok karar alınmıştır. Öğretmen yetiştirmeye yönelik kararların sayısı çok olmakla birlikte bazılarını burada belirtmekte yarar vardır. $\mathrm{Bu}$ kararlardan bazıları şöyledir:

- Öğretim kurumlarında mesleki danışmanlık ve rehberlik hizmeti sunulmalidir. 
- Öğrencilerin mesleki ve teknik orta öğretimdeki programlarının devamı sayılan öğretmenlik programlarına geçişte orta öğretim başarı puanı ve ek puan uygulamasina devam edilmelidir.

- Öğrencilerin seçiminde, ilgili alan öğretmenliğinin gerektirdiği beceri ve yetenek sınavı, ilgili mesleki ve teknik eğitim fakültelerince yapılmalıdır.

- Mesleki ve Teknik öğretmenlik mesleğinin tercih edilmesini özendirmek için; burs vermek, yurt sağlamak gibi güdüleyiciler artırılarak sürdürülmeli, yüksek lisans olanakları sağlanmalıdır.

- Orta dereceli mesleki ve teknik öğretim okullarının öğretmen ihtiyacını karşılayan temel kurumlar Mesleki ve Teknik Eğitim Fakülteleri olmalidir.

- Mesleki ve Teknik orta öğretim ve Mesleki Teknik Eğitim Fakültelerinin eğitim - öğretim programları birbiri ile ve iş hayatı ile uyumlu hâle getirilmelidir.

- Mesleki ve teknik öğretim okullarına öğretmen yetiştiren fakültelerin öğretmenlik meslek bilgisi dersleri ilgili fakültelerin görüşleri de alınarak yeniden düzenlenmelidir (MEB, 12. Millî Eğitim Şûrası,1999: 329-335).

Her alandaki öğretmenler açısından çok önemli olan ve de tüm öğretmenlere kazandırılması gereken hususlarda kararlarda yer almaktadır. "Öğretmen yetiştiren bu fakültelerin programları ezberci değil düşünen, araştıran, sorgulayan, analiz, sentez ve değerlendirme yapabilen, değişen teknolojiyi, imkân ve kaynakları etkili kullanabilen öğretmenler yetiştirecek şekilde yeniden düzenlenmelidir. Yine ilgili fakültelerde yaratıcı, eleştirel ve bilimsel düşünen, insan ve doğaya ilişkin estetik değerlere sahip olan, yeni bilgi ve teknolojiyi kullanan, yabancı dil bilen öğretmenler yetiştirilmelidir" (MEB, 12. Millî Eğitim Şûrası1,1999: 329-335) gibi kararlar meslek açısından olması gereken önemli kararlardır. Tabiî ki bunların kâğıt üzerinde kalmaması uygulamaya aktarılması çok daha önem arz etmektedir.

Bunlarla birlikte, ülkenin insan gücü ihtiyacının dikkate alınması ve buna göre eğitim kurumlarının oluşturulması, öğretmen ihtiyaçların nicelik ve nitelik olarak belirlenmesi, bu ihtiyaçların karşılanması için kısa ve uzun vadeli planların yapılması kararlaştırılmıştır. Bu planların uygulanması için Bakanlık, YÖK ve ilgili endüstriyel kurum ve kuruluşlarla iş birliği ve koordinasyonun sürekli hâle getirilmesi de karar olarak alınmıştır. 
Bu dönemde incelenen milli eğitim şuralarında görüldüğü gibi, sorunun önemine bağlı olarak oldukça uzun bir tavsiye kararları kümesiyle karşılaşılmaktadır. Bu tavsiye kararları arasında, sorunun en can alıcı noktalarına işaret edildiği görülmekle birlikte bu kararlar silsilesi içerisinde yer alan çok önemli kararların kaybolup gitme durumu da söz konusu olmuştur. Oysa bu kararlar arasında öncelik sırasına göre seçim yapılıp daha net ve güçlü önerilerin hayata geçirilmeleri sağlanabilirdi.

\section{B) Millî Eğitim Şûraları ve Öğretmenlerin Sayısal Durumları:}

Öğretmenlerin sayısal bakımdan yetersizlikleri Türk Millî Eğitim sisteminin en eski ve en temel sorunlarından birisidir. Bu sorunun aşılması için çeşitli değişik dönemlerde çeşitli uygulamaların yapıldığına Türk eğitim tarihi tanıklık etmiştir. Sayısal endişeler nedeniyle yapılanlar maalesef iyi yetişmemiş yada yarı yetişmiş niteliksiz kişilerin mesleğe girmesine yol açmış, eğitim sisteminde daha farklı sorunların ortaya çıkmasına kaynaklık etmiş ve mesleğin saygınlığının zarar vermiştir.

Bu olumsuz durum hemen her şûrada eleştirilmiş, nicelik adına niteliğin feda edilemeyeceği ve edilmemesi gerektiği şeklinde uyarılar hep yapılmıştır. Ancak 1860 yılından 2000'li yıllara uzayan süreçte buna bir çözüm getirilememiştir. Öğretmenlerin sayısal yetersizliği ve dengesiz dağılımı 12. Millî Eğitim Şûrasında da tartışılmıştır. Diğer şûralarda da bir iki cümle ile de olsa değinilmiştir.

12. Millî Eğitim Şûrasında (1988), bu sorun, okulöncesi öğretimde önemli oranda öğretmen açığı bulunduğu ve bu açığın giderilmesi için bazı tedbirlerin alınması gerektiği şeklinde gündeme gelmiştir. $\mathrm{Bu}$ ihtiyacın yükseköğretim kurumlarınca karşılanması mümkün olana kadar, mevcut öğretmenlerin yanına "öğretmen yardımcısı" veya "eğitici" verilmesi konusunda gerekli çalışmaların yapılması önerilmiştir. Ayrıca, lise ve dengi okul mezunlarının, kendilerine verilecek pedagojik formasyondan sonra bu amaçla istihdam edilmeleri (MEB, 1988)'nin kararlaştırıldığı görülmektedir. $\mathrm{Bu}$ öneri ve kararlar da göstermektedir ki öğretmenlerin sayısal olarak yetersizlikleri söz konusudur.

\section{C) Millî Eğitim Şûraları ve Öğretmenlerin Ekonomik Sorunları:}

Millî Eğitim Şûralarında, öğretmenlerin ekonomik sorunlarının fazlaca gündeme gelmediği görülmektedir. Zaman zaman bu sorunun gündeme getirildiği yerlerde de sorun kabul edilmekle birlikte öğretmenin maddi sıkıntılarını gidermekten çok mesleğe ilgiyi artırmak ve mesleği cazip hâle getirmek gerektiğine işaret edilmiş, ancak nelerin yapılması gerektiği somut olarak tartışma konusu yapılmamıştır. 
Sadece 16. Millî Eğitim Şûrasında öğretmenlerin ekonomik sorunlarının varlığı kabul edilmiş ancak bu sorunla ilgili; "öğretmenlerin sadece girdikleri ders saatleri ücrete yansitılmakta bunun dışındaki eğitim faaliyetleri ders yükü hesabında dikkate alınmamaktadır" denilmektedir. Öğretmen mesleğini yeterince icra edebilmek için onun maddi sıkıntısının olmaması, karnının doyması, iyi yiyip iyi giyinmesi, alanındaki mesleki yayınları rahatça takip edebilmesi gerekmektedir. Böyle olmayınca da öğretmen dışarıda ek iş yapmaya yönelmekte en değerli vaktini okuluna, öğrencilerine ve mesleğine harcaması gerekirken bunu dışarıda ek iş yaparak harcamaktadır.

Anılan şûrada, öğretmenlerin maddi sorunlarının çözümüne ilişkin bir öneride bulunulmuş ancak bu "ücretlendirme yapılırken, ders yükü hesabında öğretmenin katıldı ̆̆ tüm eğitim etkinlikleri ile iş güçlüğü, iş riski ve temininde güçlük faktörleri dikkate alınmalıdır"'(MEB, 16. Millî Eğitim Şûrası:1999) şeklinde genel bir ifadeden ibaret olmuştur. Burada bu ders dış1 eğitim faaliyetlerinin boyutlarının neler olduğu ve iş güçlüğü gibi kavramlara açıklık getirilmemiştir.

\section{D) Millî Eğitim Şûraları ve Öğretmenlerin Hukuki Statüleri:}

Öğretmenlerin hukuki statüleri önemli bir sorun olup bununla ilgili olarak 11. Millî Eğitim Şûrasında (1982) öğretmen yetiştirme görevinin üniversitelere verilmesi görüşü benimsenerek, öğretmen yetiştiren kurumların misyonlarını layıkıyla yerine getirememeleri durumunda öğretmenliğin herkesin yapabileceği bir meslek hâline dönüşebileceği uyarıs1 yapılmıştır. $\mathrm{Bu}$ şûrada üniversitelerin diğer fakültelerinden mezun olanların ve iş kuramayanların, bir öğretmen sertifikası ile öğretmen olabileceği ve öğretmenliğin de artık meslek olmaktan çıkacağı (MEB, 11. Millî Eğitim Şûras1,1982) ifade edilerek öğretmenlik mesleğinin meslekleşme sürecine önemli vurgu yapılmıştır.

11. Milli Eğitim Şûrasında, öğretmenlik mesleğinin herkesin yapabileceği bir meslek olarak düşünülmemesi, gerçekten bu mesleğe yatkın kişilerin programlara kaydolmasının sağlanması gereklilik olarak ortaya konmuştur. Öğretmenlerin sayısal yetersizliği konusunda kestirme çözümlere başvurulmasının hem öğretmenlik mesleğinin hukuki ve toplumsal statüsüne hem de toplumda bir meslek olarak algılanmasina olumsuz etkileri olacağının unutulmaması gerektiği de ifade edilmiştir.

Diğer yandan 12. Millî Eğitim Şûrasında da öğretmenlerin hukuki statülerine dolaylı da olsa değinildiği görülmektedir. Şûrada ele alınan Öğretmen Yetiştirme Komisyonu Raporunda bu sorunun varlığını kabul

eden ifadeler yer almaktadır. Sorun; "toplumun mimarları olan öğretmenlerin, hâlen mesleki bilgi ve becerileri çağın ihtiyaçlarına cevap 
verecek seviye de değildir. Oysa yurdun kalkınması ve milletin refah ve saadeti, öğretmenlerin iyi yetiştirilmesine ve görevlerini en iyi şekilde yerine getirmelerine bağlıdır. Eğitim sisteminin iyileştirilmesinde ve başarısında ögrretmenlerin sayı ve nitelik itibariyle yeterlilikleri konusu, Cumhuriyet döneminin başından beri önemini korumuştur. Ülkede eğitim ve öğretimin esasları ile öğretmenlik mesleğinin temel niteliklerini belirleyen 1739 Sayılı Millî Eğitim Temel Kanunu'nun 43. maddesinde: “Öğretmenlik, Devletin eğitim, öğretim ve bununla ilgili yönetim görevlerini üzerine alan özel bir ihtisas mesleğidir" (MEB; 12. Millî Eğitim Şûrası: 1988) şeklindeki ifadelerle ortaya konmuştur.

$\mathrm{Bu}$ ifadelerden de anlaşılacağı gibi, öğretmen ve mesleğin hukuki tanımı yapılmakta ve belli esasların, ilkelerin olması gerektiği vurgulanmaktadır. Öğretmenin görev ve sorumlulukları ile birlikte niteliği ve bu niteliği kazanmasında gerekli olan esaslar da söz konusudur.

Yine anılan şûranın, Öğretmenlerin Hizmet Öncesi Yetiştirilmesi bölümünde, öğretmenlerin hangi kanun çerçevesinde ve nasıl yetiştirilmesi gerektiği üzerinde durulmuş ve ilgili kararlarda, Anayasada ve Millî Eğitim Temel Kanunu'nda belirtilen amaç ve ilkelere uygun öğretmenler yetiştirilmesinde titizlik gösterilmesi gerektiği önemle vurgulanmıştır. Öğretmenlik mesleğine adayların seçiminden başlanarak öğretmen kaynağının gelişigüzellikten arındırılması, kaynak birliğinin sağlanmasına işaret edilmiştir.

$\mathrm{Bu}$ sorun ayrıca, öğretmenlerin Hizmet içi eğitimlerinin kanunla düzenlenmesi ve bu eğitim faaliyetlerine katılıp başarılı olan öğretmenlerin başarıları özlük hakları yönünden değerlendirilmesi ve bu değerlendirmenin üst görevlere getirilmede de titizlikle dikkate alınması kararlaştırılmıştır. Yine öğretmenlerin tayin ve nakilleri ile ilgili mevzuat ülkenin ihtiyaçlarına ve şartlarına uygun, ögretmenlerin tereddüt ve endişelerine yer vermeyecek şekilde ve her türlü müdahaleden uzak olarak yeniden düzenlenmesi (MEB; 12. Millî Eğitim Şûrası:1988) gerektiği de karar olarak alınmıştır.

Şûrada, bu soruna köklü çözüm getirmek amacıyla; öğretmenlerin çalışma şartları, mesleki itibar ve statülerine ilişkin olarak, "çalışma ve hayat şartları bakımından tatmin edilemeyen öğretmenlerin istenilen ölçülerde istihdamı mümkün olmamaktadır" görüşü ileri sürülerek öğretmenlik mesleğini cazip hâle getirecek teklif ve tedbirler ele alınmıştır. Burada, önce öğretmenin içinde bulunduğu durum tespit edilmiş ve yapılması gerekenler için çözüm önerileri sunulmuştur. Bunlardan bazıları şöyledir:

- Üniversite bazında daha kabiliyetli ögrrencilerin mesleğe teşviki ve yönlendirilebilmesi için en başta gelen şart, öğretmenlik mesleğine 
toplumda verilen önem ve değerin yeniden canlandırılması ve çalışma şartlart ile maaşların mesleğin haysiyetine uygun seviyeye getirilmesidir.

- Kariyer düzeni ve rekabet sistemi içinde, çalışkan ve başarll ögretmenler, unvan, maaş, üst göreve getirme ve benzeri yollarla değerlendirilmeli ve ödüllendirilmelidir.

- Ö̈̆retmen Personel Kanunu mutlaka çıkarılmalıdır.

- Her başarılı hizmet yll için 3 ay emeklilik kıdemi verilmelidir.

- Öğretmen istihdamında "Sözleşme usulü" denenmeli, yararlı olacağ gözlenir ise uygulanmalıdır.

- Öğretmenin mesleki itibarının manevi yönden de ele alınması zaruri görülmektedir (MEB;1988;298).

$\mathrm{Bu}$ tespit ve öneriler öğretmenlik mesleği için çok önemli olup mesleğe saygınlık, çekicilik kazandıracak niteliktedir. Ancak hala bu önerilerin hala hayata geçirilemediği de unutulmamalıdır.

Diğer taraftan öğretmenlerin hukuki durumlarının kısmen gündeme geldiği Millî Eğitim Şûralarından biri de, 14. Millî Eğitim Şûrası olmuştur. Şûrada, Okulöncesi eğitim alanına öğretmen yetiştirme ve istihdamı özelinde ele alınmış ancak bu kararlar diğer öğretmenlik alanlarında uygulanabilir özellik göstermesine karşın bu kararların meslekleşmeyi sağlayacak, buna katkı getirecek hususların olmadığı, sadece öğrenci kaynağı konusunda yol gösterici nitelikte olduğu görülmektedir. Yine okulöncesi eğitime öğretmen yetiştiren yüksek öğretim kurumlarına öğrenci seçimi ile öğretmenlerinin özlük haklarının iyileştirilmesi için gerekli tedbirlerin alınması ve lisansüstü eğitim yapmalarına imkân sağlanması (MEB,1993) kararı önemlidir. Görüldüğü gibi öneriler hukuki statü ile ilgili bazı ölçütler getirmekle birlikte konunun çok da önemsenmediğini göstermektedir.

Öğretmenlerin Hukuki Statülerine kısmen ve dolaylı olarak değinen son şura ise; 16. Millî Eğitim Şûrası olmuştur. Bu sorun, mesleki ve teknik öğretmenlerin özlük hakları ve istihdamı ile gündeme gelmiştir. Yine burada tespit edilen sorunlar ve bunların çözümüne yönelik öneriler genele teşmil edilebilecek nitelikte olmakla birlikte sadece sorunun tespitinin yapıldı $\breve{g} 1$, sorunun kaynaklarının ortaya konduğu görülmektedir. Ancak güçlü, kalıcı çözümlerin getirilmediği görülmektedir. Sorun öğretmen ihtiyacını karşılamada kaynak birliğinin olmadığı ve farklı kaynaklardan bu ihtiyacın karşılandığ1, öğretmen arz ve talebinde nitelik ve nicelik açısından dengesizliklerin olduğu ifade edilmiştir. Öğretmenlerin ekonomik ve sosyal 
statülerinin kendilerinden beklenenlerle uyumlu olmadığ 1 , bununda öğretmenlerin statülerinin diğer meslek gruplarına göre daha düşük kaldığını göstermesi açısından önemlidir. Bunların yanında öğretmenlerin, sicil, terfi, tayin konularında çok ciddi sorunlar yaşamakta olduğu ve öğretmenlerin performansının sağlıklı bir biçimde değerlendirilemediğine işaret edilmiştir.

Bazı yanlış uygulamalardan kaynaklanan bu sorunların çözümüne ilişkin öneriler de yine komisyon tarafından tavsiye edilmiştir. Bu önerilerin bazıları şöyledir:

- Öğretmenlere; görev, yetki ve sorumluluklarına uygun sosyal ve ekonomik bir statü kazandırılmalıdır.

- Öğretmenlerin ilk atamalarında arz fazlasının olması hâlinde, kur'a ile atama yerine sınavla en başarılı olanlar atanmalıdır.

- Öğretmenlerin çalışma koşulları iyileştirilmelidir. Emekli olan öğretmenlere emeklilik sonrası yaşam standartlarını yükseltecek yasal düzenlemeler yapılmalıdır.

- Mesleki ve teknik eğitim fakültelerinin mezunlarının görev, yetki ve sorumlulukları belirlenmelidir.

- $\quad$ Eğitim programlarında mesleğe ilişkin yasal ve yönetsel düzenlemelere yer verilmelidir (MEB, 16. Millî Eğitim Şûras1, 1999: 272-276).

$\mathrm{Bu}$ önerilerde görüldüğü üzere, öğretmenlerin hukuki statülerine ilişkin yaşanan sorunların önemli bir kısmının kaynağında, öğretmenlerin atanma, kadro, ekonomik şartlarının iyi olmaması, yer değiştirmeleri ve bunlara ilişkin esasların sağlam kurallara bağlanamayışı bulunmaktadır. $\mathrm{Bu}$ sorunların aşılmasında, sağlam geleneklerin, uygulamaların oluşturulması ve bunun siyasal iktidarların müdahalelerine açık olmaktan kurtarılmasının önemli rol oynayacağ 1 dolaylı olarak anlatılmaktadır.

\section{E) Millî Eğitim Şûraları ve Öğretmenlerin Örgütlenme Sorunları}

Öğretmenlerin örgütlenme sorunu, öğretmen sorunları içersinde eski ve önemli bir sorun olmasına rağmen resmi toplantı ve metinlerde hak ettiği yeri hiçbir zaman alamamıştır. Mesleğin saygınlığ 1 ve sorunlarının çözümü açısından son derece önemli olan örgütlerin uzun yıllar ihmal edilmesi, görmezden gelinmesi, yasal zemininin oluşturulamaması mesleği olumsuz etkilemiştir. Çeşitli eğitim ve öğretmen sorunlarının tartışıldığı bu Şûralarda bu sorun ya görmezden gelinmiş, yok sayılmış yada hak ettiği değer verilmemiştir. Bunun bir sorun olarak görüldüğü tek şûra ise 16. Millî Eğitim Şûrası olmuştur.

16. Millî Eğitim Şûrasında, öğretmenlerin örgütlenme sorunlarına ilişkin olarak sadece "öğretmenlerin ortak mesleki değerlerini korumak ve 
geliştirmek amacıyla sendika kurmalarını kolaylaştıracak, yeterli yasal ve yönetsel düzenlemeler mevcut değildir"(MEB, 16. Millî Eğitim Şûras1, 1999: 272) ifadesi yer almıştır. Bu ifade ile bunun önemli bir eksiklik olduğu görülmektedir. Bu eksikliğin ortaya çıkardığı eğitim ve öğretmen sorunlarına işaret edilerek bu sorunun çözümüne ilişkin öneri de komisyon tarafindan ortaya konmuştur. Söz konusu öneri; "öğretmenlerin ortak mesleki değerlerini korumak ve geliştirmek amacıyla sendika kurmalarına imkân verecek yasal düzenlemeler yapılmalıdır" (MEB, 16. Millî Eğitim Şûrası,1999;272) şeklinde kararlarda yer almıştır. Bu Millî Eğitim Şûrası toplantısından sonra kısmi de olsa öğretmen örgütleri ile ilgili yasal düzenlemelere gidilmesi arzu edilen noktanın uzağında da olsa önemli bir gelişme olmuştur.

\section{F) Millî Eğitim Şûraları ve Öğretmenlerin Mesleki Yayınları}

Öğretmenlerin kendilerini yetiştirip geliştirmeleri hep onlardan istenmiştir. Ancak öğretmenlerin kendilerini yetiştirmeleri mesleki yayınlarla mümkün olacaktır. Öğretmenlere hitap eden mesleki yayınlar ise önemli bir öğretmen sorunu olup öğretmenler, bu yayınlarla mesleğe ve meslektaşlara ait sorunları ve bunlara ilişkin çözüm önerileri gündeme getirebilirler, kamuoyu oluşturabilirler. Öğretmenler arasında haberleşme de sağlanabilir. Öğretmenlerin mesleki yayınları için önce öğretmeni istihdam eden MEB ile öğretmen örgütlerine görev ve sorumluluklar düşmektedir. Ancak gelişmiş, güçlü örgütlerin olmadığı yerlerde mesleki yayınlardan söz etmek olası değildir.

Öğretmenlerin bu sorunu, bir eğitim ve öğretmen sorunu olarak ilgililerce önemli görülmemiş, yeterince değerlendirilmemiş olduğu söylenebilir. Çünkü araştırma kapsamında yer alan Millî Eğitim Şûralarında öğretmenlerin mesleki yayınlarına ilişkin gerek sorun ve gerekse çözüm noktasında belirgin bilgilere ulaşılamamıştır. Sonuç olarak mesleki yayın konusunun, Millî Eğitim Şûraları gibi geniş katılımlı ve bilimsel toplantılarda bile ele alınmamış olması bu sorunun yetkililerce dikkate alınmadığı, sorun olarak değerlendirilmediğini ve önemsenmediğini göstermektedir.

\section{TARTIŞMA VE SONUÇ}

Öğretmen sorunları Türk eğitim sisteminin en eski ve köklü sorunlarından biridir. Türk eğitim sisteminin sorunlarına ilişkin her türlü bilimsel çalışma ve toplantılarda öğretmen sorunları da tartışma konusu yapılmaktadır. Öğretmenlerin yetiştirilmesinden istihdamına ve özlük haklarına kadar pek çok sorunu var olmuş ve bunlar çeşitli bilimsel araştırmalara konu olmuştur. Eğitime ilişkin sorunların ve çözüm 
önerilerinin tartışıldığı Millî Eğitim Şûralarında da öğretmen sorunları, eğitim sisteminin en temel sorunlarından birisi olarak ele alınmıştır. Ancak bu bilimsel toplantı ve çalışmaların, Türkiye'de özellikle öğretmen sorunlarının çözümünde ne derecede önemsendiği, uygulayıcı ve çözüm üretme konumunda olan Bakanlığın ve Hükümetlerin, bu bilimsel çalışma ve toplantılarda ortaya konulan çözüm önerilerinden de yeterince yararlanmadığ 1 ve yararlandı ise hangi düzeyde yararlandığ 1 arzu edilen düzeyde bilimsel çalışmalara konu edilmediği görülmektedir.

Öğretmen sorunlarının ele alınıp tartışıldığı toplantıların en başında Millı̂ Eğitim Şûraları gelmektedir. Cumhuriyet döneminin ilk yıllarından günümüze, başka isimlerle de olsa çeşitli tarihlerde bu tür toplantılar yapılmıştır ve hâlen yapılmaktadır.

Millî Eğitim Şûralarında, ağırlıklı olarak öğretmen sorunlarından öğretmenlerin yetiştirilmesi sorunu üzerinde durulduğu diğer öğretmen sorunlarının ise fazla ele alınıp tartışılmadığ 1 , ele alınan sorunların ise yüzeysel ve kısmî olarak tartışıldığı görülmektedir. Şûralarda kısmen gündeme gelen öğretmen sorunlarından biriside öğretmenlerin hukuki statü sorunları olmuştur. Ancak bu sorun bazı şûralarda yer bulurken bazılarında ise hiç yer bulamamıştır.

Şûralarda, ögretmenlik mesleğinin sorunları ve çözüm yolları sürekli tartışılmış, yeni çözüm önerileri, yeni modeller önerilmiştir. $\mathrm{Bu}$ toplantılarda, sorunun varlığı hep kabul edilmiş ancak bunlara köklü bir çözüm getirilememiştir. Öğretmenliğin önemli bir meslek olduğu, önemli görev ve sorumluluklarının bulunduğu ve mesleğin kutsallığı sözü sürekli tekrarlanmıştır. Olumlu birçok girişimde ise istenen sonuç alınamamıştır. Birinci Heyet-i ilmiye'yi Temmuz 1923'te toplayan dönemin Millî Eğitim Bakanı İsmail Safa (Özler) yapmış olduğu açış konuşmasında Millî Eğitim Bakanlığının bilimsel eğitim toplantılarına ilişkin nasıl bir tutum takınması gerektiğini açıklamıştır. Bu sözler eğitim tarihinin bize gösterdiği çok önemli bir soruna işaret etmektedir. Buna göre, Millî Eğitim Bakanlığının izleyeceği politikaların yalnızca Bakanın ve yetkililerin kendi isteklerine göre belirlemesinin uygun olmadığı, bütün eğitim meseleleri üzerinde memleketin uzmanlarından, fikir adamlarından, eğitimcilerinden ve sosyal bilimcilerinden oluşan bir topluluğun bilimsel ve müspet kararları doğrultusunda belirlenmesi gerektiğidir. Bilimsel kararlara dayanmadan doğru ve kalıcı bir iş yapmak, sorunlara kalıcı çözümler getirmek mümkün görülmemektedir. Millî Eğitim Bakanlığı, ülkenin bilim adamalarının ve düşünürlerin karar ve fikirlerini uygulayacak bir araç olmalıdır. Böylece bakanlar değişse bile bilimsel temele dayalı olarak alınan kararlar, yine 
bilimsel yeni bir karar alınmadıkça değişmemeli ve uygulamaya konulmamalıdır. Ancak uygulamaların böyle olmadığı da görülmektedir.

Başka bir ifade ile eğitim ve öğretmen sorunlarına ilişkin değerlendirme ve çözüm önerileri bilim adamlarınca ve bilimsel yöntemlerle tespit edilmelidir. Öğretmen sorunları günü birlik politikalara alet edilmemeli, politik çekişmelerin dışında tutulmalıdır. Millî Eğitim Bakanlığı ise ortaya konan fikir ve kararların özünden sapmadan uygulayıcısı ve takipçisi olmalıdır. Her Bakan'a göre politika ve uygulama değişmemeli, Bakanlık politik kaygılarla değil bilimsel verilerle hareket etmelidir. Millî Eğitim Şûraları, eğitimin diğer sorunlarının olduğu gibi öğretmen sorunlarının çözümünde de etkili ve önemli bir role sahip olmalı, aldığı kararlarda da daha işlevsel olmalıdır.

\section{KAYNAKLAR}

Akyüz, Y. (1971); “Türkiye’de İlk Öğretmen Kuruluşları Hakkında Orijinal Bir Belge ile Unutulmuş Bir Kaynak”. Eğitim Fakültesi Dergisi, Cilt: 3, Sayı: 1-4 (Ankara; 1971).

Akyüz, Y. (1978); Türkiye'de Öğretmenlerin Toplumsal Değişmedeki Etkileri (1848-1940). Ankara: Doğan Basımevi: 1978.

Akyüz, Y. (1987); "Tarihi Süreç İçinde Öğretmen Yetiştirme Sorunları", "Öğretmen Yetiştiren Yüksek Öğretim Kurumlarının Dünü-BugünüGeleceği Sempozyumu”. Gazi Üniversitesi Gazi Eğitim, Gazi Mesleki Eğitim ve Teknik Eğitim Fakültesi. Ankara:1987.

AKYÜZ, Y.(2002); "Dünden Bugüne Öğretmenlik Mesleğine Bir Bakış", Çağdaş Eğitim, Ankara: Nisan 2002, Sayı; 286.

Akyüz, Y. (2006); "Çağdaş Anlamda Türkiye'de "Öğretmenin Saygınlı̆̆ı" Kavramının Doğuşuna Eleştirel Bir Bakış". Eğitime Bakış Dergisi. Y11:2, Sayı:5, Ocak-Şubat- Mart. 2006, Ankara.

Akyüz, Y. (2007); Türk Eğitim Tarihi (M.Ö.1000-M.S. 2006). Ankara: PegemA Yay. (Genişletilmiş ve Yeniden Yazılmış 11. Baskı)

Altunya, N. (1998), Türkiye'de Öğretmen Örgütlenmesi (1908 - 1998), Ankara.

Aydın, R. (1999), Türk Basınında Öğretmen sorunları(1940-1955 yılları Aras1). (Basılmamış Yüksek Lisans Tezi) Ankara Üniversitesi Sosyal Bilimler Enstitüsü, Ankara:1999. 
Balcı, Ali. (2001), Eğitimde Bilimsel Araştırma Yöntemleri. Ankara.

Duman, T. (1987); “Öğretmen Yetiştirmenin Sosyal ve Kültürel Temelleri”, "Öğretmen Yetiştiren Yüksek Öğretim Kurumlarının Dünü-BugünüGeleceği Sempozyumu”. Gazi Üniversitesi Gazi Eğitim, Gazi Mesleki Eğitim ve Teknik Eğitim Fakültesi: Ankara:1987.

Duman, T. (1991); Türkiye'de Orta Öğretime Öğretmen Yetiştirme (Tarihi Gelişim). İstanbul: Millî Eğitim Basımevi.

Duman, T. (1998); "Cumhuriyetimizin 75 Yılında Öğretmen Yetiştirme Sistemimiz ve Sorunları". Milli Eğitim Eğitim-Sanat- Kültür Dergisi. Ankara: Temmuz-Ağustos-Eylül 1998, Say1:139.

Duman, T. (2005); “Türkiye'de Öğretmen Yetiştirmenin Tarihçesi”, "Eğitim Fakültelerinde Yeniden Yapılanmanın Sonuçları ve Öğretmen Yetiştirme Sempozyumu". Gazi Üniversitesi Gazi Eğitim Fakültesi. Ankara: 22-24 Eylül 2005.

Eke, K. (1983); “Başöğretmenimiz Atatürk'ün Eğitim İlkeleri”, Çağdaş Eğitim Dergisi. Yı1: 1983, Cilt: 8, Sayı:83.

Ergün, M. (1987); “Tarihi Süreç İçerisinde Türkiye'de Öğretmen Yetiştirme Sorunu", "Öğretmen Yetiştiren Yüksek Öğretim Kurumlarının DünüBugünü-Geleceği Sempozyumu”. Gazi Üniversitesi Gazi Eğitim, Gazi Mesleki Eğitim, Teknik Eğitim Fakültesi. Ankara:1987.

Gurbetoğlu, A. (2007); “II. Meşrutiyet Döneminde Yayınlanan Çocuk Dergilerinin Eğitim Açısından İncelenmesi”. Ankara Üniversitesi Eğitim Bilimleri Enstitüsü, Yayımlanmamış Doktora Tezi, Ankara: 2007.

Karagözoğlu, G. (1986); "Yüksek Öğretime Geçişte Öğretmenlik Mesleğine Yönelme" Hacettepe Üniversitesince Düzenlenen Çağdaş Gelişmeler Işığında Türkiye'de Eğitim Fakültelerinin Yeri ve Rolü Uluslararası Sempozyumu. Ankara.

Karasar, N. (2005); Bilimsel Araştırma Yöntemleri, "Kavramlar, İlkeler ve Teknikler" Ankara:PegemA Yay.

Kavcar, C. (1974); "Eğitimimizde Nicelik-Nitelik ve Öğretmen Sorunu", Ankara Üniversitesi Eğitim Fakültesi Dergisi. Y1l: 1974, Cilt: 6, Say1:1-4.

Kavcar, C. (1999); "Nitelikli Öğretmen Sorunu", "Öğretmen Eğitiminde Çağdaş Yaklaşımlar Sempozyumu". Buca Eğitim Fakültesi Dergisi, Özel Say1:11, Yı1: 1999. İzmir. 
Kaya, Y. K. (1984). İnsan Yetiştirme Düzenimiz "Politika / Eğitim / Kalkınma. Ankara:1984.

MEB, (1981); 10. Milli Eğitim Şûrası. Ankara: 23 - 26 Haziran 1981.

MEB, (1982); 11. Milli Eğitim Şûrası. 8 - 11 Haziran 1982 Ankara

MEB, (1988); 12. Milli Eğitim Şûrası. 18 - 22 Temmuz 1988 Ankara

MEB, (1990); 13. Milli Eğitim Şûrası. 15 - 19 Ocak 1990 Ankara

MEB, (1993); 14. Milli Eğitim Şûrası. 27 - 29 Eylül 1993 Ankara

MEB, (1996); 15. Milli Eğitim Şûrası. 23 - 27 Eylül 1996 Ankara

MEB, (1999); 16. Milli Eğitim Şûrası. 22 - 26 Şubat 1999 Ankara

MEB, (1982). “Öğretmen Sorunları ve Eğilimleri Araştırması”. Ankara.

MEB, (1996); Yönetici ve Öğretmenler İçin Kanun El Kitabı. MEB Yay. Ankara:1996.

Oktay, A. (1991); “Öğretmenlik Mesleği ve Öğretmenin Nitelikleri”. Eğitim Bilimleri Dergisi, Y11:1991, Say1:3 Marmara Üniversitesi Atatürk Eğitim Fakültesi.

Öğretmen Yetiştirme ve Eğitim Fakülteleri (1982-2007), T.C. Yükseköğretim Kurulu Yay. Ankara:

Tekışık, H. H. (1982)."Öğretmen Yetiştirme ve Öğretmenlik Mesleğinin Sorunları", Çağdaş Eğitim Dergisi. 7,67, Mayıs 1982.

Tekışık, H. H. (1995). “Atatürk'ün Öğretmenleri”, Çağdaş Eğitim Dergisi, 20, 215, Kasim -1 
